\title{
Structure, Diversity and Adaptive Traits of Seasonal Cycles and Strategies in Ants
}

\author{
Elena B. Lopatina
}

Additional information is available at the end of the chapter

http://dx.doi.org/10.5772/intechopen.75388

\begin{abstract}
This chapter is a review of data on structure, diversity and adaptive properties of seasonal cycles in ants. Most tropical ants demonstrate homodynamic development. They do not show any developmental delays and all-year round the ontogenetic stages from egg to pupa exist in their nests. Some of the quasi-heterodynamic species have permeated into the regions with warm temperate climate but a true diapause did not evolve. Most temperate and all boreal climate ants are true heterodynamic. They manifest a real winter diapause (prospective dormancy) in their annual cycle. Thus, a variety of forms of dormancy, which were found in ants, extend from elementary quiescence to deep diapause. Heterodynamic ants use two main seasonal strategies with respect to brood rearing: strategy of concentrated brood rearing (Formica type) and strategy of prolonged brood rearing (Aphaenogaster type, Myrmica type). The larval stages at which diapause can occur are extremely variable among ants. The evolution of seasonal life cycles and possible ways of origin of diapause in ants are discussed. The subtropical (quasi-heterodynamic) and tropical (preadaptational) evolutionary paths to true heterodynamic development are considered. It is concluded that similar seasonal adaptations could arise in the evolution of ants independently many times and usually are not tightly bound to the taxonomic position of species.
\end{abstract}

Keywords: Formicidae, ants, seasonal development, life cycles, homodynamic, heterodynamic, diapause, exogenous, endogenous, temperature, climate, evolution

\section{Introduction}

The life of ants as ectothermic organisms is closely connected with the seasonal variations of ecological factors, such as temperature, rainfall, humidity, availability of food, etc., occurring 
during the year. Certain climatic changes usually manifest even in tropics and cause the corresponding modifications in behavior and development of ants and other insects, but they are much more pronounced on the north. In the regions with temperate and boreal climate, the annual changes of climatic conditions possess a hard impact to the life cycles of all organisms living there. In different ant species, various annual cycles of behavior arise. They have been described in many reviews (for example, see [1, 2]). However, the seasonality of the behavioral cycle in ant colonies is strictly subordinated to the seasonality in developmental processes such as oviposition or larval rearing. Each ant species demonstrates certain annual developmental cycle because the processes of the colony development cannot proceed without interruption during the whole year.

To optimize the survival and growth of ant colonies, the entire warm season should be used for larvae rearing and for production of the greatest quantity of new adults. That is why the brood development should start in spring as earlier as feasible and prolong as longer as possible in late summer. At the same time, only the brood stages that are able to survive during the winter should occur in ant colony by the end of autumn. To ensure this, the special physiological mechanisms evolved which provide synchronization of the colony development with the yearly climatic periodicity.

The first investigations devoted to seasonality in the development of ants were performed by Yozhikov who studied the phenology of the development in several ant species from Central Russia [3]; by Headly who characterized the seasonal development of two Leptothorax species and Aphaenogaster fulva aquia in North America [4, 5]; by Talbot who carried out the phenological studies on two North American Myrmica species [6]; and by Eidmann who described the hibernation in ants and mentioned that the Formica species overwinter without a brood [7].

Despite extensive studies of arthropod dormancy and seasonality, myrmecologists paid very little attention to the role of seasonality in ant ecology, as well as in the evolution of the life cycles of these social insects. Literature on this topic is not rich. Quite a few publications specifically devoted to seasonal development and the phenology of ants. As a rule, such data can be found in the investigations dealing with the biology and ecology of certain species. Even less frequently, the subject of the study was the regulation of annual cycles of the ant development. Most often, these problems were affected accidentally and stood in the background and pushed back by the main aims of the study (for example, see [8]). The seasonal development of the ants Myrmica was studied to the greatest extent, mainly due to the works of M. Brian (for reviews, see [1, 8-10]).

This paper contains a review of literary and proprietary data on the structure, diversity, adaptive features and evolution of seasonal cycles and strategies of the seasonal development in ants. We have studied the seasonal cycles in more than 80 species belonging to more than 20 genera from different regions of Russia and the former USSR, ranging from warm temperate to cold temperate and boreal climatic zones. Our field and laboratory studies have allowed us to map the diversity of annual cycles, to reveal the underlying ecophysiological and social mechanisms of control and to develop ideas on possible pathways in the evolution of the seasonal cycle in ants.

The main study methods we have used were laboratory experiments and field phenological observations. In experimental studies, the ant colonies were divided into fragments each 
consisted of workers, queens and the brood. In the case of a small number of workers in the colony or for monogynous species with a single queen in the nest, entire natural colonies were used. Colony fragments (or the whole colonies) were kept in artificial plastic nests, which were randomly distributed over various experimental regimes (different photoperiodic conditions and constant temperatures or thermal periods) and experimental regimes were maintained in special thermostats. Our methods of laboratory cultivation of ants provided the opportunity to observe and to study all stages of annual cycle including the overwintering in a refrigerator under the temperatures of $3-5^{\circ} \mathrm{C}$.

\section{Peculiarities of seasonal development in ants as social insects}

In social insects, in addition to the life cycles of individual individuals, there is a life cycle of the colony, as an integrated, superorganismic system. It consists of the processes of the development of individuals, but it is not equivalent to a simple summation of them. Social regulation mechanisms arise in the evolution and are realized through interactions between members of the colony. They control the physiological state and the development of individuals, depending on the ecological situation and colony needs. Such "collective regulation" of development is absent in solitary species and largely determines the specificity of seasonal development in ants [11-16].

Colonies of ants are not only perennial but usually have unlimited life cycle under favorable conditions of environment [17]. Not only queens but even workers can survive for several years. In monogynous species, all workers and the brood are the offspring of the only queen. So while the queen is alive, all the population of a colony can relate to one and the same genetic generation during consistent years. In polygynous species with several queens in a nest, all individuals inhabiting a single colony may pertain to various generations which overlay each other. However, the seasonal life cycle of the colony is not associated with differences arise between generations. It embraces the regular seasonal variations in physiological state of all individuals in a colony which entail the orderly changes in behavioral and developmental patterns. Therefore, we determined the seasonal life cycle of an ant colony as the annual cycle of physiology, behavior and development [18].

After the spring awakening, the queen commences laying eggs, the development of larvae begins and pupae appear. There are workers and reproductive individuals among new adults. Oviposition and brood development continue throughout the warm period of the year and cease in the autumn, when insects begin to prepare for wintering, go to special shelters and spend the winter in inactive state. The annual cycle of colony development is a collective and highly organized process and includes the individual development of immature stages (the brood) and regular seasonal changes in the physiological state and reproductive activity of adults (workers and queens). That is why the growth and development and the beginning and termination of diapause in ants can be considered and studied both in individual level and at the level of the entire colony. And this is not the same thing, since all these processes are under the control of the mechanisms of social regulation and integrated reactions of the colony to the changes in environmental conditions. In this 
connection, diapause of ant larvae can be (and usually happens) facultative at the level of an individual, but at the same time obligatory at a colony level (in endogenous-heterodynamic species).

\section{Homodynamic type of seasonal development}

On the general background of an insufficient study of the phenology in ants, the tropical regions of the Earth are especially prominent. Analysis of meager data shows that at any time of the year, in the nests of most tropical species studied, all the stages of ontogenesis from the egg to the pupa are present, and development retardations are absent. Such continuous allyear round development without the obligatory onset of periods of physiological dormancy we call homodynamic, using the terminology of E. Roubaud [18-21].

However, homodynamic species often have a certain seasonal structure of the annual cycle: on a general background of continuous development, there may be significant seasonal fluctuations in the number of certain ontogenetic stages, as well as seasonal association of the rearing of alates and nuptial flights. Thus, in Cataulacus guineensis from Ghana, the brood population has two maxima-in May and in September, the alate females and males are numerous in the nests in July-October, and the rest of the time there are few or none alates at all [22]. The larvae of alate reproductives of Camponotus sericeus in India develop from October to July, and alate females and males can be found in nests all-year round, but their nuptial flight occurs in September-October [23, 24]. Colonies of the tropical ant Paltothyreus tarsatus (Republic of Côte d'Ivoire) grow alate females in spring, and males in autumn; reproductives live in maternal nests for a long time and leave for mating only in February [25]. In definite periods of the year, alates of Anoplolepis longipes are grown up in Papua New Guinea [26] and in the Seychelles [27] and alates of Camponotus detritus in Namibia [28]. The factors that cause such seasonality in tropical species are not yet clear enough.

In addition, periodicity of oviposition was noted for a number of species. For example, in the natural colonies of Anoplolepis longipes, Cataulacus guineensis and species of the genus Rhytidoponera [29], there are two egg abundance maxima throughout the year. Rhythm of oviposition was also found in a tropical species Linepithema humile, widespread in Southern France, both in natural and laboratory conditions [30]. The periodicity of egg laying is also a characteristic feature of the nomadic ants of the tropical subfamily Dorylinae and especially of the Neotropical species. In all species, the cyclic brood rearing is clearly associated with behavioral cycles: oviposition occurs during stationary phase of reproductive cycle that alternates with nomadic phase, during which the ants feed the larvae that emerge from the eggs [31-33].

The homodynamic development of some tropical ants was observed in the laboratory. G. Terron maintained colonies of the African species Tetraponera anthracina at $25-26^{\circ} \mathrm{C}$ for several years and reported that development of the brood occurred continuously and reproductives periodically appeared [34]. But he observed alternating periods of egg laying and reproductive dormancy of queens. The ant Monomorium pharaonis, a widespread synanthropic species, which was imported from tropical Africa to Europe and North America, now inhabits many heated buildings. It was found that in the nests of this species under optimum conditions $\left(27-30^{\circ} \mathrm{C}\right.$, 
relative to 60-65\%), brood developed continuously with cyclic rearing of alate reproductives at regular intervals [35-41]. We also kept several colonies of M. pharaonis found in St. Petersburg in the laboratory for 2 years and revealed that at any temperatures above the threshold, which is $17.7-17.8^{\circ} \mathrm{C}$ in this species [42], brood development occurred without any delays. However, at a near-threshold temperature of $17^{\circ} \mathrm{C}$, the mortality rate of all brood categories, as well as of adult ants, sharply increased, and the colonies died within a month. Thus, this tropical species cannot tolerate even short periods of temperature decrease, which confirmed by the available data on its habitation in Europe only in heated buildings [43].

We observed homodynamic development in two species from tropics: Pheidole sexspinosa from the Tonga archipelago and the Tetramorium semillimum from the Seychelles. We kept them in the laboratory for more than a year, varying the temperature and photoperiod within acceptable values, i.e. within those that can be observed in the natural habitat of these species $\left(18-25^{\circ} \mathrm{C}, 10-16\right.$ hours of light per day). All this time, there was a continuous development in the colonies.

It is well known that typically tropical insects cannot survive for a long time at temperatures well below the optimum and, especially, below the developmental threshold [44]. Therefore, it can be argued that the tropical ants in their majority are not adapted to survive during the cold periods of the year. However, some ant species can demonstrate continuous all-year round development even in subtropical environments. For example, in the central regions of Texas (USA), Pseudomyrmex sp. occupies the stems of a mimosa, and all ontogenetic stages are present year round, but in different amounts: eggs and larvae are numerous in winter and pupae in spring and summer [45]. Thus, we can assume that the development and pupation of larvae of this species continues in winter, but much more slowly than in summer. This decrease of brood developmental rate leads to a significant decline in the number of pupae in wintering nests. According to Rissing, new workers of Messor (Veromessor) pergandei in Arizona (USA) appear from pupae also throughout the year [46].

\section{Heterodynamic cycles of development}

Annual developmental cycles of ant colonies, in which a diapause arises naturally, we call after Roubaud heterodynamic [18-21]. They have a distinct seasonal structure: the period of diapause (the phase of dormancy) is regularly replaced by the period of development (the active phase of the cycle), after which a new period of diapause occurs, and so on. Generally, the phase of dormancy in the annual cycle coincides with the period of unfavorable climatic and (or) food conditions. It is characterized by a lack of larval development and, as a rule, of queen oviposition and the presence in the nests of only certain (usually diapausing) brood categories. During the active phase of the annual cycle, eggs are laid and the larvae are reared. Ants grow up new workers, as well as alate females and males.

\subsection{Quasi-heterodynamic development}

Some ant species recently penetrated from tropics or subtropics to areas with a warm temperate climate and successfully settled there. Two species of fire ants, Solenopsis richteri and 
S. invicta, were imported to the United States from South America: the first one, around 1920, and the second one, in the early 1940s [47, 48]. S. invicta significantly expanded its original range fairly far north and is now prevalent in most southeastern states [48, 49]. The distribution of S. richteri is limited mainly to the northern parts of Alabama and Mississippi and the southern part of Tennessee [50].

Several authors have shown that in southern United States (Mississippi, Florida, South Carolina, etc.) both fire ant species remain essentially homodynamic: eggs, larvae and pupae of workers are present in their nests all-year round [48, 51, 52]. However, the number of immature stages varies considerably during the year, and in winter, it is very small. In FebruaryMarch, the number of eggs increases sharply and new larvae develop and begin to pupate in April (workers) and May (alates). At this time, the quantity of brood categories is maximal and reaches $40-45 \%$ of the entire biomass of the colony. Reproductive individuals appear from pupae in June and fly out of the nests at least five times during the summer. The second small peak of the brood population (up to $35 \%$ of the biomass) in the nests coincides with the first cooling in September-October. At this time, all larvae and pupae belong only to the caste of workers. In November-December, the number of larvae and pupae sharply decreases and reaches a minimum (less than $2 \%$ of the biomass of the colony) in January. Thus, the number of immature stages in fire ants directly depends on the environmental temperature.

It has been determined that in the most northern populations of S. invicta, oviposition and brood development are suspended in the coldest months, i.e. eggs and pupae are absent in the nests in winter $[48,53]$. It can be assumed that there is no diapause of larvae in fire ants and larval development ceases only when the ambient temperature falls below the developmental threshold, which is about $17^{\circ} \mathrm{C}$ according to laboratory experiments [54]. We can also assume that many eggs, larvae and pupae (as well as adult ants) die during the winter in northern populations of this species. The winter mortality of S. invicta workers was noted in several works (for example, [55]). Nevertheless, the colonies successfully survive in these conditions. Consequently, these ants already have some physiological adaptations that allow them to tolerate a sufficiently long stay at low positive temperatures.

Such tropical species, adapted to live in regions with cold winters without forming real diapause, we call quasi-heterodynamic [18]. They are characterized by the potential for unlimitedly long development under favorable conditions inherent in homodynamic species. The development of their brood ceases only at temperature below the developmental threshold and ants spend the winter in a quiescent (cold coma) state suffering from more or less strong mortality, but in general the colonies overwinter successfully.

The Argentine ant Linepithema humile demonstrates another example of quasi-heterodynamic development. This tropical species was imported from South America and now widespread in many parts of the world. Its phenology, investigated in the USA [56] and in Europe [30], is very similar to the seasonal development of fire ants. In the southern part of California, only a few larvae of workers and very few eggs can be found in overwintering nests of this species. At this time of year, more than $90 \%$ of the colony biomass is made up by adult ants. The new seasonal cycle begins in late February-early March, when the queen starts to lay eggs. The larvae hibernated in the nests complete their development by the middle of March. In summer, brood makes up about $50 \%$ of the colony biomass, but in October its number decreases 
sharply and gradually reaches its minimum by December. On the southern coast of France, the Argentine ant has similar phenology. Most small larvae hibernate in the nests, but in small numbers, and there are also some medium and large larvae and very rarely eggs. Renewal of development is observed in March.

Since the fire ants and Argentine ants recently permeated to the areas with cold winters, we tend to think that they do not yet have diapause. However, it has been experimentally determined that only the overwintered colonies of the Argentine ant can grow up a lot of alate females, which appear in the nests in the south of France at the beginning of the summer season [57]. This suggests that there are seasonal changes in the physiological state of colonies that are similar to diapause.

According to the literature date, many subtropical ants do not have any brood in their nests during the winter, for example, Ponera pennsylvanica in the state Missouri [58], Pogonomyrmex rugosus and P. subnitidus in Southern California [59] and Prenolepis imparis in the states Missouri, Ohio and Florida [60-62]. However, without experimental laboratory studies, it is impossible to conclude whether all of them are quasi-heterodynamic and overwinter without brood due to its death, or, conversely, they have a stable winter diapause of the queens, i.e. belong to the group of true heterodynamic species.

We discovered and investigated quasi-heterodynamic developmental cycles in several ant species living in regions with subtropical and warm temperate climates. In the colonies of Tetramorium nipponense and Pachycondyla chinensis, which were collected in the south of Japan and were kept in the laboratory at temperature of $25-27^{\circ} \mathrm{C}$ and photoperiod of $16 \mathrm{~h}$ of light per day, the oviposition of queens and the development and pupation of larvae did not cease during the year. After a gradual decrease in temperature, the colony successfully overwintered at $7-8^{\circ} \mathrm{C}$. At the same time, however, all brood died, which probably occurs during the overwintering in natural conditions of the south of Japan.

In the experiments on Monomorium kusnezovi from Turkmenistan, the growth, development and pupation of larvae continued uninterruptedly at temperatures exceeding the developmental threshold of $20^{\circ} \mathrm{C}$ for eggs and $21.5^{\circ} \mathrm{C}$ for larvae and prepupae [42]. Thus, larvae of this species do not have diapause, which is a sign of quasi-heterodynamic seasonal cycle. At $20^{\circ} \mathrm{C}$, the larvae ceased growth, but the oviposition did not stop, and by the beginning of overwintering, eggs and larvae of all ages were still present in the nests. However, eggs, as a rule, did not survive during hibernation in the laboratory, but the larvae hibernated more successfully. We assume that, in natural conditions, these ants go on hibernation with eggs and larvae, but eggs and part of the larvae die during the winter. In the middle of April in the Central Kopet Dag when we dug out the nests of M. kusnezovi, we always found small packets with eggs and larvae of younger instars and a small number of the third instar larvae lying separately, which already began to pupate at this time of a year. Obviously, these larvae overwintered in the nests but the eggs could appear in the early spring. Thus, it seems likely, though not completely proved, that a certain number of eggs can be preserved in the nests of M. kusnezovi until spring.

Two Pheidole species (P. pallidula and P. fervida) were collected in Turkmenistan and Russia, where they inhabit the regions with temperate climate. They also proved to be quasi-heterodynamic. P. pallidula is common in southern Europe, the Caucasus and Central Asia [63]; the 
distribution area of P. fervida includes Southeast Asia, Japan, southern Kurils and the south of Primorye [64]. In Primorye, P. fervida probably survived from the Tertiary period, when the climate there was much milder. In our experiments with both species, the queens continued to lay eggs and the larvae developed and pupated at any temperatures exceeding the developmental threshold (about $18^{\circ} \mathrm{C}$ for P. pallidula [42]). Any forms of diapause were absent. Under optimum conditions at $25-28^{\circ} \mathrm{C}$, we observed continuous development for two or more years.

For P. pallidula from Turkmenistan, we found that when the temperature decreased to $20^{\circ} \mathrm{C}$, the queen's productivity declined significantly, but queens did not stop laying eggs, and the larvae developed and pupated. At a temperature of $17^{\circ} \mathrm{C}$, which is only slightly below the developmental threshold for eggs and larvae, oviposition continued, but the eggs did not develop. Pupae and prepupae were the first to die, and then all brood stages gradually perished. Consequently, it could be assumed that in nature all brood in the nests of this species die even before the beginning of winter. Our field studies in Turkmenistan have shown that there was no brood in the nests of $P$. pallidula in early spring indeed. It appeared later from the eggs laid by queens. This is confirmed by the observations made by Passera [65-67] in the south of France.

P. fervida is somewhat better adapted to the temperate climate in the south of Primorye and its brood probably dies out only partially during overwintering. In our experiments with autumn colonies of this species, even at a temperature of $17^{\circ} \mathrm{C}$ and under short day conditions (10 hours of light per day), the queen continued oviposition, and larvae still pupated. We maintained one colony, in which there were originally more than a hundred larvae of different size, under these conditions during 7 months. Over this time, some of the larvae perished, but more than half of them pupated. This situation was strikingly different from the one we observed in similar experiments with truly heterodynamic ants: in most cases at $17^{\circ} \mathrm{C}$, the development very quickly ceased due to the onset of diapause.

When we decreased the keeping temperature for the autumn colonies of $P$. fervida up to $10-12^{\circ} \mathrm{C}$, the workers began to dismember and to throw out the prepupae and pupae from the nests and gradually destroyed them all. There were only eggs and larvae of all instars in the nests. However, part of the eggs and larvae of the first and second instar perished during the hibernation in the refrigerator at $3-5^{\circ} \mathrm{C}$, while the older larvae overwintered more successfully. It would be extremely interesting to compare the population of the colonies of this species in late autumn and early spring to assess the ability of the larvae to survive during the winter in natural habitats. Probably, the similar regulation of the seasonal developmental cycle exists in Pheidole morrisi, which hibernates with larvae in the north of Florida [68].

\subsection{True heterodynamic development}

Most temperate and all boreal climate ants are true heterodynamic. They possess real winter diapause in their annual cycles (prospective dormancy) [18]. The presence of this diapause provides a more successful wintering by increasing the physiological resistance of larvae and adult ants to unfavorable winter conditions. In the literature, there is practically no data on the tolerance of developing and diapausing larvae, other developmental stages and adult ants to low temperature and other unfavorable environmental factors. Plateaux [69] noted that Temnothorax nylanderi in an active physiological state could not successfully overwinter: 
when he put summer colonies of this species into the refrigerator, eggs, pre-pupae and unpigmented pupae quickly died and began to rot, causing the death of the entire colony. Similar results were obtained in our experiments with colonies of Lasius niger, Lepisiota semenovi, Myrmica rubra, M. ruginodis and Plagiolepis compressus, which we put in the refrigerator at a temperature of about $5^{\circ} \mathrm{C}$ in summer. Eggs, pre-pupae and pupae died within $1-3$ weeks, but larvae remained alive.

True heterodynamic seasonal cycles occur in the vast majority of ant species living not only in temperate and cold climates, but also in subtropics and even in tropics. The presence of longterm developmental delays was noted, for example, in all five species from the Rhytidoponera impressa group, widespread in the forests of Eastern Australia. These species demonstrated a strict seasonality of development: during the winter months, only small and medium-sized larvae and very rarely eggs were found in their nests. This situation was observed both in subtropical and tropical regions of Australia [29].

It is clear that for the occurrence of heterodynamic development in tropics, any seasonal changes in environmental conditions have to exist. Since the annual rhythm of the climate is usually quite distinct in the tropical regions, and its absence, on the contrary, is very rare situation, heterodynamic seasonal cycles should probably be widespread in tropical ants. The hibernation and diapause are widespread in tropical insects, but mechanisms of the regulation of heterodynamic cycles in tropics are far from understanding and explaining yet [70].

It should be assumed that heterodynamic development is more common for ants in subtropics, because the seasonal rhythm of the climate there is much more pronounced than in the tropical zone. Indeed, most of the subtropical species studied demonstrate the cessation of development in winter. Some of them do not have brood, while others overwinter with larvae: Camponotus kiusiuensis [71], C. nawai [72] and Leptanilla japonica [73] in southern Japan, Temnothorax monjanzei in Algiers [74] and T. melas on the Corsica island [75], Tapinoma minutum in New South Wales [76], Polyrhachis vicina in southern China [77, 78] and Pheidole morrisi [68] and Dolichoderus mariae [79] in the north of Florida. However, it is impossible to decide without special experiments whether these subtropical ants possess a real diapause, or they are quasi-heterodynamic and stop their development during the cold season due to direct influence of low temperature.

\section{Two seasonal strategies of brood rearing in heterodynamic ants}

Analyzing the structural diversity of heterodynamic seasonal cycles in ants, we identified two fundamentally different directions in their evolution, and accordingly, two seasonal strategies for brood rearing [18].

\subsection{The strategy of prolonged brood rearing}

The ants are more likely to follow the strategy of prolonged brood rearing. This strategy is based on the ability of larvae to enter into a diapause and to continue development over the 
next summer (Figure 1). Depending on the composition of the overwintering brood and the stage at which diapause is observed; we distinguish two structural types of developmental cycles [80].

Aphaenogaster type. Larvae fall into a diapause at the end of summer and all the remaining pupae manage to complete the development before the onset of colds, but the queens have no diapause and do not cease oviposition until the late autumn. Therefore, not only diapause larvae but also eggs and young larvae overwinter and survive, at least partially, during the winter. Thus, the formation of the wintering population of the colony is determined by the appearance of larval diapause in species with this type of seasonal cycle. These species are apparently limited in their distribution by subtropics and the southernmost regions of the temperate zone.

Myrmica type. The diapause starts both in larvae and queens at the end of summer. Therefore, before the winter comes, larvae emerge from the laid eggs, and all pupae develop into adults. The overwintering brood is represented only by larvae. This annual cycles are typical for most ant species living in a temperate climate zone. The induction of diapause in both larvae and queens plays an equally important role in the synchronization of Myrmica type cycles with the annual rhythm of the climate and in the formation of the wintering composition of the colony.

The annual cycles of ants that overwinter with brood have the most complex seasonal structure (Figure 1). All hibernating larvae usually pupate during the summer season. They give the first peak in the number of pupae in the nests. As a rule, alate females and males develop from most of them. Some of the larvae that emerged from the eggs which were laid in spring and early summer can pupate during the same growing season. This is the so-called a rapid or summer brood, according to Brian [81, 82]. It develops without diapause and gives the second peak in the number of pupae. All other larvae that emerge from the eggs within the season, fall into a diapause, hibernate and finish their development only next summer. This

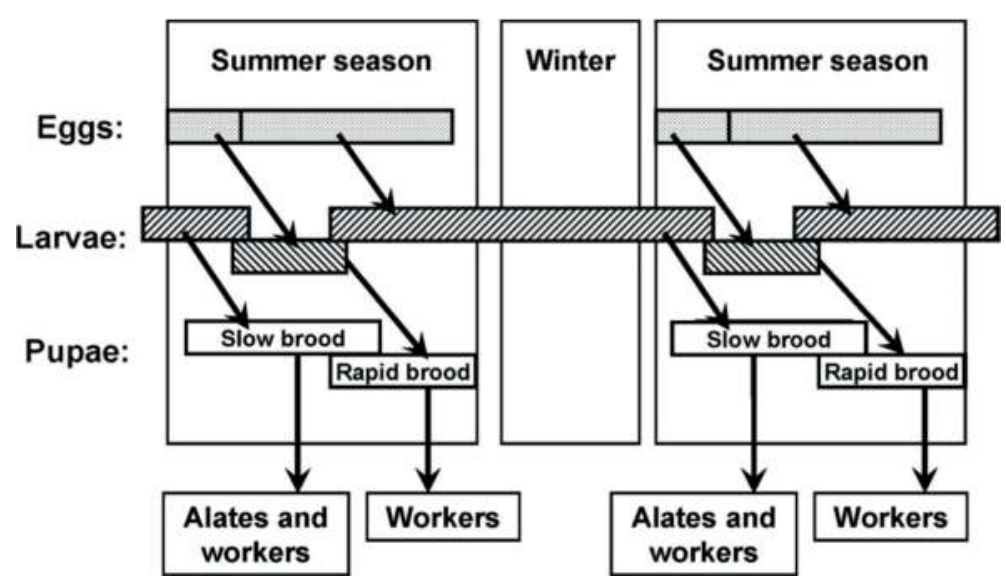

Figure 1. The strategy of prolonged brood rearing. Further explanation in the text. 
is so-called a slow or winter brood [81, 82]. Thus, two complete cycles of brood development from the egg to imago take place in a colony during each year (Figure 1): a summer cycle that begins and ends within one growing season, and a winter cycle, in which larval development is interrupted by their diapause.

Rapid brood is found in most species from the temperate zone. It may be absent in species and populations from the northern regions, where summer is short, as well as in species with very slow individual development. For example, the rapid brood is absent in Amblyopone pallipes from Massachusetts [83]. It can be assumed that this species is characterized by very slow development, although there are no data on this problem. The Japanese ant Leptanilla japonica has an extremely specialized annual cycle without rapid brood [73]. The queen lays the only portion of eggs at the end of July to the beginning of August. The larvae develop, overwinter at the last instar and pupate in July of the following year. They develop very synchronously, so that at each moment there is only one ontogenetic stage in the nest. Adults emerge from pupae at a time when larvae appear from the next portion of eggs. Thus, in spite of the fact that this species lives in subtropical climate, only one cycle of brood development occurs during a year.

The strategy of prolonged brood rearing is extensive inherently, as it is realized by stretching of the development of individuals for two or more summer seasons. The appearance of larval ability to fall into a diapause gave the ants a unique way for adaptation to the life in a temperate climate and especially in high latitudes. Therefore, the strategy of prolonged development is most common among the ants living there. It has a number of adaptive advantages.

\subsubsection{More complete use of a favorable period for the development and available thermal resources}

Since the larvae are always in the nest, the workers can feed them from early spring to late autumn. Immediately after the end of the winter, as soon as it becomes a little warmer, the ants carry larvae from the underground chambers to the upper, warmed by the sun, horizons of the nest (beginning with the largest larvae), creating the best opportunity for larval growth and development. As it becomes warmer and the amount of available food increases, the ants carry more and more small larvae to the upper levels of the nest and begin to feed them. According to Peakin for Lasius flavus, the overwintered larvae of the first and second instars remain in the deep and cold nest chambers for the longest time and therefore complete their development only by the end of the summer [84]. Just the same was recorded for Temnothorax nylanderi by Plateaux $[69,85]$. In the spring, the workers of this species also start with the feeding of the largest overwintered larvae which develop into alates.

The autumn period of larval rearing is also of great importance for most ants with a wintering brood. For example, in the central part of European Russia in the colonies of M. rubra, the pupation of larvae ceases, as a rule, in the first half of August due to the onset of larval diapause. However, until the middle of September, the larvae continue to hatch from remaining eggs, to grow and develop. New third instar larvae appear and soon fall into a diapause. Moreover, in Myrmica diapausing, third instar larvae retain their ability to feed and to grow slowly (without 
the development of imaginal buds), and therefore, they continue to gain the weight in the autumn period $[9,86]$. The same autumn growth of the last instar larvae was observed in Leptothorax species [69]. According to our data, larval growth in diapause state is a characteristic feature primarily for species in which larvae enter into a diapause and overwinter in the last or all instars, Aphaenogaster, Lasius, Leptothorax, Manica, Messor, Myrmica, Solenopsis, Temnothorax and Tetramorium and a number of species in genera Camponotus, Crematogaster and Monomorium.

Thus, in the species using the strategy of prolonged brood rearing, workers are engaged in feeding of larvae until the final onset of cold weather and give them all the surplus food produced during this period (minus the amount of nutrients that the workers accumulate in their fat body). This makes it possible to maximize the total mass of the wintering brood and, consequently, to grow up earlier the first workers, as well as reproductives, next spring. In addition, the biomass accumulated by larvae is also a reserve of nutrients for the colony: in the case of food shortage, ants can eat a part of the brood (mainly eggs and small larvae) in order to survive and to feed the largest larvae $[2,87]$.

\subsubsection{The ability to adapt to the duration of the warm period of a year by changing the amount of the rapid brood}

Such adaptation path can be realized during the penetration of the ants into more northern areas [88] and in connection with the local variability of climatic conditions from year to year. In the north, where summer is short and heat resources are limited, the ants can grow up much less number of the rapid brood than in the south. For example, in the south of France, Temnothorax unifasciatus has numerous rapid brood, and in cooler Belgium, only small amount of it [89]. According to our data for Lasius niger, L. flavus, Myrmica rubra, M. ruginodis and M. scabrinodis from the central part of European Russia, all overwintered larvae pupate in the spring and in the first half of summer, and then a numerous rapid brood larvae also pupate. Simultaneously, at the latitude of St. Petersburg, where the warm resources available to the ants of these species are much less, usually only a small part of larvae emerging from the eggs pupate during the same summer.

In the far north, where the summer is even shorter and the warmth is even less than in St. Petersburg, the ants generally never have rapid brood [88]. This was demonstrated in our studies on Leptothorax acervorum and Myrmica kamtschatica from the upper reaches of the Kolyma River and M. rubra and M. ruginodis from the coast of the White Sea near the Arctic Circle. Similar changes in the amount of rapid brood occur when the average summer temperature increases or decreases from year to year. For example, in cool summer, Temnothorax nylanderi may have no rapid brood, although it is usually quite numerous [69]. We observed the same in St. Petersburg region for Lasius niger, Leptothorax acervorum, Myrmica rubra, M. ruginodis and $M$. scabrinodis, in colonies of which there was no rapid brood in cool years, and even some larvae could stay for repeated overwintering.

\subsubsection{The ability to stretch the development of larvae for two or even three summer seasons}

Lack of thermal and/or nutritional resources during the summer is not uncommon situation in areas with cold temperate climate. As a result, some overwintered larvae that do not reach 
the size sufficient for pupation, fall into a diapause repeatedly and hibernate the second time. Repeated overwintering of some larvae was noted for Camponotus aethiops [90], Temnothorax nylanderi [69], Leptothorax acervorum [91], T. grouvellei [92] and Myrmica rubra [93]. We observed this phenomenon in our experiments with Aphaenogaster sinensis, Camponotus herculeanus, C. japonicus, C. aethiops, Lasius niger, L. flavus, Leptothorax acervorum, Manica rubida, Myrmica rubra and M. ruginodis. The possibility of repeated larval hibernation is of particular importance for ants living in the far north with an extremely short summer. According to our data for Myrmica kamtschatica and Leptothorax acervorum from the upper reaches of the Kolyma River, all wintering larvae pupate in warm years, but only a part of them if the summer is cold.

However, the number of larvae repeatedly overwintering probably cannot be significant in the colony. This is hampered by some social factors that limit possible changes in the structure of the seasonal developmental cycle when ants penetrate into more northern regions [88]. Therefore, ants never go over to the opportunistic strategy of stretching development for several years, so typical for many boreal and arctic insects [94, 95]. This feature restricts further spread of ants to high latitudes.

\subsection{The strategy of concentrated brood rearing (Formica type)}

This strategy presumes the obligatory completion of the development of larvae emerging from the eggs during one summer season, i.e. is typical for species that hibernate without brood (Figure 2). We named such annual cycles as Formica type [80], since they were first described for ants of this genus [7]. Diapause in larvae is absent, but it arises in queens at the end of summer long before the autumn cooling. Therefore, even the eggs laid by the latter have time to complete the development. All adults emerge from the pupae before cold weather comes on, and the ants prepare to overwinter. We can say that all brood is rapid in these ants.

After the onset of queen diapause, new eggs stop to appear and all existing brood gradually completes development. The diapause of queens should not occur too early, otherwise the period available for brood development would be actually reduced. Simultaneously, if diapause arises too late in the season, many larvae and pupae would be caught by the onset of winter and destroyed by the cold. That is why the moment when queens enter into a diapause is the most important for the Formica type annual cycles. From the point of view of using available heat resources, the strategy of concentrated brood rearing is less effective than the strategy of prolonged development. It can be realized in a temperate climate zone, where summer is short, only in the combination with increased brood developmental rate, i.e. by intensifying developmental processes, which becomes extremely important for northern species and populations living in areas with a particularly short summer.

Our studies have shown $[42,96]$ that this is really so: in Cataglyphis, and especially in Formica, individual developmental rates are significantly higher than in most species with hibernating larvae. Among the northern ants, Formica species have the shortest developmental times and develop almost twice as fast as Myrmica and Leptothorax. All six Formica species which we have studied were very similar in the duration of ontogenesis and the temperature sensitivity of the development [42]. Moreover, the development of Formica is much more thermal sensitive 

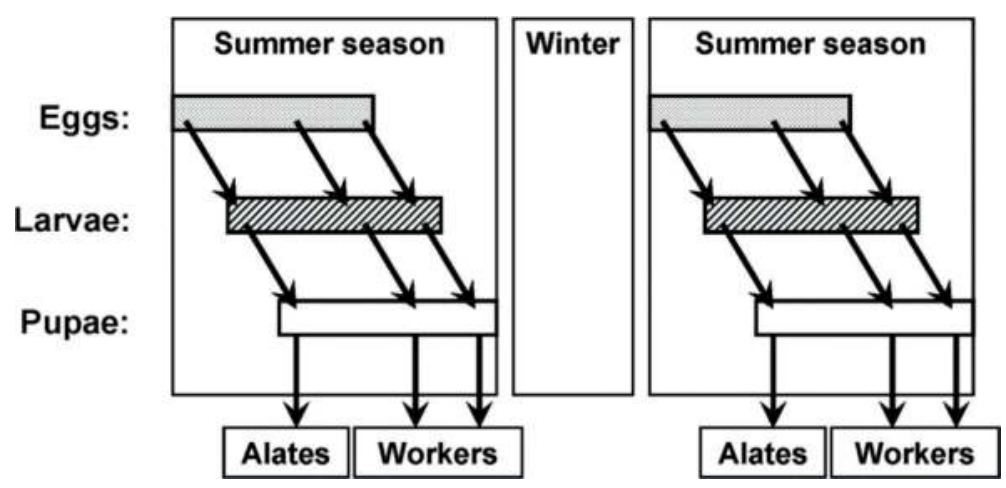

Figure 2. The strategy of concentrated brood rearing. Further explanation in the text.

than in Myrmica, due to relatively higher temperature thresholds and a higher coefficient of linear regression of the developmental rate on temperature, which allows Formica ants to rear brood especially intensively at higher temperatures $[42,96]$.

According to our data, at temperatures of $25-26^{\circ} \mathrm{C}$ close to optimum temperatures for Formica species, their developmental time from the egg to the pupa is only $20-25$ days, while it is 34-35 days in M. rubra. Moreover, at temperatures optimal for $M$. rubra (about $22^{\circ} \mathrm{C}$ ), their developmental time from the egg to the pupa is $40-45$ days, i.e. almost twice as much as Formica species. Thus, in Formica, brood rearing really occurs more intensively. In concordance with our observations for Serviformica species, in European Russia, their development from the egg to the adult can be consistently realized two or three times over the summer, i.e. these ants can rear two or three large batches of the brood. In Myrmica species, only one full cycle of development, rapid brood, passes in the colony during the summer season. The larvae of the second cycle enter into a diapause, overwinter and finish development next summer.

Thus, it can be assumed that raised rate of ontogenesis in Formica species completely compensates for the shortcomings of the strategy of concentrated development and allows to significantly increase the total amount of brood reared in the temperate climate during the summer. So far, however, it is difficult to say whether such a high rate of ontogenetic processes is a special adaptation that appeared in evolution during the formation of annual cycles of Formica type, or the strategy of concentrated development could arise only in ants that already had a high rate of development as preadaptational.

\section{Review of heterodynamic annual cycles in ants}

\subsection{Seasonal cycles of Aphaenogaster type}

For the first time, the seasonal cycle of ants of the genus Aphaenogaster was described in the work of Headley [5], who counted the quantitative composition of 46 colonies of A. fulva aquia (= rudis) in Ohio and recorded that eggs and larvae of all sizes remained in the nests 
for hibernation. These data were confirmed by Talbot, who conducted research on A. fulva and $A$. rudis in the more southerly state of Missouri $[58,97]$ and much later by Mizutani and Imamura on A. japonica in Sapporo (Japan) [98].

We found and investigated this annual developmental cycle on $A$. sinensis (Southern Primorye, Russia), A. gibbosa (southwestern Turkmenistan) and A. subterranea (Crimea) and suggested to separate it into a particular type [80]. Apparently, it is typical for the whole genus Aphaenogaster. In three species studied by us, a diapause of larvae of the last (third) instar arises at the end of summer. However, queens continue to lay eggs until late autumn, thus they do not have diapause. Therefore, eggs and larvae of all three instars stay in the nests for overwintering. At least some of the eggs and junior larvae hibernate successfully, both in the laboratory and in nature. We confirmed this fact during the excavation of nests in the south of Primorye and in the Western Kopet Dag (Turkmenistan) in early spring. In accordance with our data, the same seasonal cycle is typical for Tapinoma erraticum, T. karavaievi and, possibly, for some Messor species in Turkmenistan, as well as for Temnothorax species, although, in all these species, eggs cannot so successfully overwinter.

Thus, of all the currently known ants from the temperate climate going on hibernation with eggs, they probably overwinter happily only in the Aphaenogaster species. The incapacity of the eggs for hibernation is an obvious consequence of the impossibility of diapause onset at this ontogenetic stage in ants. Our experiments with the colonies of Lepisiota semenovi, Lasius niger, Myrmica rubra, M. ruginodis and Plagiolepis compressus, which we placed in summer into a refrigerator with a temperature of $3-5^{\circ} \mathrm{C}$, have shown that the eggs of these ants died at low temperatures for 2 to 3 weeks and, of course, could not survive for a fairly long winter in the natural habitat.

Despite this, in subtropics and in areas with a very warm temperate climate, where winters are mild and short, seasonal cycles of Aphaenogaster type, which are characterized by the absence of queen diapause and overwintering with eggs and larvae of all instars, are likely to be widespread among ants. This is confirmed by some data. Thus, living in subtropics Linepithema humile [56], Polyrhachis vicina [77, 78], Solenopsis invicta, S. richteri, Rhytidoponera impressa [29] and R. metallica [99], always overwinters with eggs and all instar larvae. The presence of eggs and larvae of all instars in the nests during the winter and even the oviposition of queens at low autumn and winter temperatures are noted for Leptothorax niger, L. raeless and Temnothorax recedens in the south of France in a very warm temperate climate, almost subtropical climate [100]. Therefore, it seems obvious that the heterodynamic annual cycles of Aphaenogaster type are of subtropical origin. Some species can later penetrate into areas with a warm temperate climate, while retaining the "subtropical" structure of their cycle. However, in this case, eggs perish during the overwintering period due to more severe winter conditions.

Most species of the genus Aphaenogaster, including those studied by Headley [5] and Talbot $[58,97]$, are also confined to tropics and subtropics [2]. It can be assumed that some representatives of this genus, which have spread from subtropics to areas with colder and more prolonged winter, evolved some physiological mechanisms that increased the viability of eggs at low temperatures. To ascertain their nature, special investigations are needed. Thus, 
according to the literature and own data, in addition to Aphaenogaster species [5, 58, 80, 97, 98], the same seasonal cycle is typical also for some species of Leptothorax, Messor, Polyrhachis, Rhytidoponera, Tapinoma and Temnothorax, inhabiting areas with a subtropical and warm temperate climate.

\subsection{Seasonal cycles of Myrmica type}

The first studies of annual cycles of such type were fulfilled in the USA by Headley on two Leptothorax species [4] and by Talbot on M. schencki emeryana [6] and on two Temnothorax species [101]. Then, Passera studied in detail the seasonal development of Plagiolepis pygmaea in Southern France [102, 103], and Sanders investigated three Camponotus species in the south of Canada [104, 105]. The seasonal cycles of Messor capitatus [106], Camponotus vagus [107] and C. aethiops [108] in the south of France, Myrmica rubra in Belgium [109] and Paratrechina flavipes in Japan [110] were studied in the same detail.

The first study, in which the annual cycle of development was observed in the laboratory, belongs to Brian [81]. He maintained two colonies of M. rubra and M. ruginodis, in artificial conditions closest to natural. Later, he investigated the growth and development in several colonies of the same species, founded by females, before the production of alates [93]. The developmental cycle of Plagiolepis pygmaea [103] and a number of Leptothorax species [69, 75, $85,89,92,111,112]$ were studied in much greater detail. Plateaux kept the colonies founded by the inseminated females of Leptothorax under conditions simulating the change of seasons, from the moment of the colony foundation until the queen death and the natural extinction of the colony (5-12 years), i.e. recorded the complete ontogeny of all colonies [75, 92, 111, 112]. Similar studies have been conducted on Messor syriacus [113], M. incorruptus [114] and M. barbarus $[115,116]$. Based on literature data, we can include in Myrmica type, the seasonal developmental cycle of European species Messor harvester [117] and Dolichoderus mariae [79] from the north of Florida (USA).

The larval stages, on which the diapause can occur, are extremely variable among ants with Myrmica and Aphaenogaster types of annual cycles. Five groups can be distinguished according to the instar composition of overwintering larvae [18].

\subsubsection{Diapause in early (1st-3rd of 5 or 6) instars (Lepisiota, Plagiolepis, Tapinoma and some Camponotus)}

Larvae of the first three instars hibernate in Plagiolepis pygmaea according to Passera [102, 103]. Our data for P. calvus, P. compressus, P. karawajewi and P. vladileni are completely consistent with this conclusion. In Tapinoma erraticum from France, most of the larvae hibernate at the first instar and only a few at the second and third [118]. We found the same in T. erraticum and T. karavaievi from Turkmenistan. We also observed the hibernation of the first and second instar larvae in Lepisiota semenovi from the same place.

Diapause in early instars is also typical for many Camponotus species. Larvae of European C. vagus always hibernate in the first instar [107]. Mintzer observed the same in incipient colonies of seven American Camponotus species (C. clariothorax, C. festinatus, C. laevigatus, C. modoc, C. planatus, C. rasilis and C. vicinus) under the laboratory conditions [119]. 


\subsubsection{Diapause in middle (2nd-4th of 5-6) instars (Camponotus s. str.)}

Sanders indicated that in C. herculeanus, C. noveboraceus and C. pennsylvanicus, living inside tree trunks in southern Canada, hibernating larvae could be divided into two distinct size classes, i.e. they were clearly at different instars, unlike the Camponotus species listed above $[104,105]$. We observed the hibernation of larvae of the second, third and in a small number of the fourth instar in our experiments on C. herculeanus, C. japonicus and C. ligniperda, all belonging to the same subgenus Camponotus s. str. The first instar larvae never overwintered. In the natural nests of $C$. herculeanus in early spring, we also found mainly larvae of the second and third instar, but did not find larvae of the first and fifth instars at all.

\subsubsection{Diapause in the late (3rd-4th of 4) instars (Harpagoxenus, Leptothorax, Temnothorax and Messor)}

According to the literature data, the larvae of Messor incorruptus hibernate in the last two instars [114]. Delage noted that among the overwintering brood of $M$. capitatus there were no larvae of the first instar [106]. In the laboratory, we observed the hibernation of M. denticulatus, $M$. intermedius, M. subgracilinodis and M. structor and found that their larvae overwintered in the last (third and fourth) instars. In the nests of M. denticulatus and M. structor from Turkmenistan in the early spring, we always found only larvae of the last two instars.

Our investigations demonstrated that in Leptothorax and Harpagoxenus sublaevis larvae hibernated in the third and fourth instars, and larvae of the latter instar were clearly predominant among them. Only very rarely single larvae of the second instar could be found in overwintering colonies of these species. Larvae of Temnothorax may hibernate at all three instars, but larvae of the last instar obviously predominate among overwintering ones, for example, in T. lichtensteini, T. nylanderi, T. parvulus [69, 112], T. grouvellei [92], T. melas [75] and T. monjanzei [74]. We observed the same in T. unifasciatus and T. tuberum.

\subsubsection{Diapause in the last (usually 3rd) instar (Manica, Diplorhoptrum, Leptanilla, Monomorium, Myrmica, Tetramorium)}

Only larvae of the third (last) instar hibernate in all Myrmica species studied [109, 120-122]. Our studies on M. bessarabica, M. kamtschatica, M. lacustris, M. rubra, M. ruginodis, M. sabuleti, M. scabrinodis and M. transsibirica confirmed this. Larvae overwinter in the latter instar also in Leptanilla japonica, which inhabit the subtropical regions of Japan [73]. Our research work allowed us to supplement this group with the following species: Monomorium gracillimum, M. ruzskyi, Manica rubida, Solenopsis celatum, S. fugax and all Tetramorium species.

Larvae of the ants, hibernating at the last instar, are for the most part far from the completion of development, i.e. they are at the beginning or in the middle of this stage. To achieve the size required for pupation, they usually need a fairly long period of growth after overwintering. This fully applies to the largest of overwintering larvae that develop in spring into alate reproductives. An exception to this rule is Leptothorax acervorum and probably other species of the same subgenus, in which many of the larvae of reproductives almost complete their development before the winter. 


\subsubsection{Diapause in all (of 3-6) instars (sometimes except the first instar) (Aphaenogaster, Crematogaster, Lasius, Paratrechina, Camponotus, Tanaemyrmex)}

This group includes Lasius flavus [84], L. alienus and L. niger (own data), Paratrechina flavipes [110], Crematogaster bogojawlenskii (own data) and some species of Camponotus. An exact study of the instar composition of overwintering larvae of $C$. aethiops in France showed that $85 \%$ of them were larvae of the first and second instars, $5 \%$ of the third to fourth and $10-15 \%$ of the fifth instar [108]. The results of our experiments and spring excavation of nests in nature confirmed that the overwintering brood of this species was represented by larvae of all instars except the first, with the obvious dominance of the second instar. We have shown that larvae of C. bactrianus and C. xerxes, species of the subgenus Tanaemyrmex as well, also hibernated in all instars except the first. Perhaps this feature is typical for the entire subgenus.

\subsection{Seasonal cycles of the Formica type}

According to the literature data and own observations, this annual cycle is typical for the ants of the entire tribe Formicini (genera Alloformica, Cataglyphis, Formica, Proformica, Rossomyrmex). This fact was firstly determined by Holmquist on Formica ulkei [123, 124] and later repeatedly confirmed by other researchers for same [125] and other Formica species: F. fusca [7], F. haemorrhoidalis [126], F. japonica [127] and F. yessensis [128]. Annual developmental cycles of ants of the subgenus Formica s. str. have been studied in detail by many authors (for example, see [129-132]). There are also detailed experimental data for Cataglyphis cursor [133-135]. Many species of genera Alloformica, Cataglyphis, Formica and Proformica have been studied in Central Asia by Dlusskii $[63,136]$. The seasonal cycle of the slave-maker ant Rossomyrmex proformicarum in the deserts of Semirechie (Republic of Kazakhstan) was described by Marikovskii [137]. Our experiments and field observations made it possible to add to this list Cataglyphis aenescens, C. emeryi, C. nodus, C. pallida, Formica cinerea, F. clara, F. cunicularia, F. gagatoides, F. lemani, F. picea, F pratensis and Proformica epinotalis.

Outside the tribe Formicini, annual cycles without wintering brood were found in Dolichoderus plagiatus, D. pustulatus [138] and D. quadripunctatus [139, 140] and in American harvester ants Pogonomyrmex occidentalis and P. montanus [59, 141, 142]. Prenolepis impairs from the north of Florida also overwinters without brood but has completely special annual cycle [60,62]. These ants are active outside the nests and foraging from November to March, i.e. during the winter months; the rest of a year the nests are closed. During the foraging period, workers inside the nest accumulate reserve nutrients in the fat body and gradually become physogastric. In spring, their mass exceeds the normal by $2-3$ times. During spring and summer, the ants stay in the nests in inactive state. In September, the queens lay a large number of eggs, and then their ovaries again become dysfunctional. The ants feed the larvae emerging from eggs only at the expense of fat stocks of physogastric workers. Both workers and winged reproductives grow up from this single batch of brood. By the time of the resumption of foraging, there is no brood in the nests.

We found the annual cycle of Formica type in Ponera coarctata from the southern coast of the Crimea (Karadag). Investigation of several dozen nests in early September demonstrated that brood, except for a small number of pupae, was no longer present in them. In the colonies 
transferred from natural nests to the laboratory, the eggs did not appear even when the ants were kept at a long day photoperiod and at temperatures of $25-28^{\circ} \mathrm{C}$ for 2 months. Thus, the reproductive diapause of queens in this species was as stable as that of Formica ants. According to Talbot, Ponera pennsylvanica in Missouri (subtropics) also hibernated without brood [58]. Similar seasonal cycle was described for another Ponerine ant, Odontomachus brunneus from the north of Florida (subtropics) [143]. This species spend half of a year (from November up to April) without any brood in the nests. This allows us to assume that queens of Odontomachus brunneus have winter reproductive diapause.

\section{Two types of the regulation of heterodynamic annual cycles}

The main characteristic feature of homodynamic and quasi-heterodynamic types of annual cycles is a purely exogenous control of the development, and the key factor is environmental temperature. Heterodynamic species have a much more complex regulation of seasonal development, usually based on a combination of exogenous and endogenous mechanisms. We divided all heterodynamic ants into two groups, which differ substantially in the principles of the regulation of the annual cycle, exogenous-heterodynamic species and endogenousheterodynamic species [18].

The first of them is characterized by the possibility of continuous and unlimited development under optimal conditions. The diapause is optional and occurs only when the temperature is lowered. Such annual cycles we call exogenous-heterodynamic. They are typical for all species of the genera Messor, Monomorium, Solenopsis and Tetramorium we have studied and also for Camponotus xerxes and Tapinoma karavaievi. At temperatures above $25^{\circ} \mathrm{C}$, as well as at diurnal thermal periods $20 / 30^{\circ} \mathrm{C}$, they all behave like true homodynamic species. Under these conditions, we observed continuous development without any signs of deterioration in experimental colonies for two or more years [144]. At the same time, at temperatures below $23-25^{\circ} \mathrm{C}$, the egg laying and the larval pupation soon stop, or only pupation (in some species of Messor, which can hibernate with eggs), i.e. development finishes under the influence of suboptimal temperatures. If the temperature is then raised, the development will resume after a while. However, it can again be blocked by lowering the temperature, and once again stimulated by its increase. Similar experiments can be repeated with the same colony of ants many times and oft with the same result [144].

Thus, exogenous-heterodynamic species are distinguished by facultative winter diapause in larvae and queens. Developmental delays in a colony are purely exogenous and ensue as a straight reaction to the influence of external environmental factors, primarily, of temperature when it becomes not optimal for the development. Moreover, inhibition of development is unstable and easily disrupted when the temperature rises. However, these developmental delays are not just a consequence of cold coma but, namely, are the form of diapause (for more details, see [18]). This is not a state of elementary quiescence as in species with quasiheterodynamic annual cycles, because this kind of diapause starts when environmental temperature still significantly exceeds the developmental threshold. Other essential feature is that the diapause arises not directly after the temperature decline but with some lag. Additionally, 
this diapause is invertible and may be terminated or induced again several times by consistent rising or decreasing the temperature, but each time after a little delay. The second important property of exogenous-heterodynamic species is the distinct change of their reaction to temperature during overwintering as a result of cold reactivation. After natural overwintering or after exposure in a refrigerator to $3-5^{\circ} \mathrm{C}$ during $2-3$ months, the development and pupation of larvae recommenced and proceeded for a long period at $20^{\circ} \mathrm{C}$ and even at $18^{\circ} \mathrm{C}$ (in some Tetramorium) in all species studied [144]. This difference in the reaction to temperature is another indication of the existence of diapause in exogenous-heterodynamic species.

Most of the ants from temperate zone belong to the second group of species which is characterized by endogenous-heterodynamic annual cycles. The diapause arises due to internal factors (endogenous timer) and no external conditions can prevent it [18, 145]. Even under long day conditions and optimal temperatures, including the diurnal thermal periods, which are the most favorable thermal conditions for ants [146-148], the development in colonies of these species necessarily ceases, and the phase of dormancy in the annual cycle begins.

Thus, the diapause of endogenous-heterodynamic species is obligatory for the colony which has an internally limited intrinsic seasonal cycle of brood rearing. External environmental factors, such as temperature and photoperiod, also participate in the regulation of annual cycles of these species, playing a corrective role, i.e. in varying degrees adjusting the duration of the cycle to the climatic peculiarities of a particular summer season. But the regulation of the cycle is still based on processes that are endogenous for the colony [18, 145]. According to our data, the following species living in temperate climate belong to the group with endogenous-heterodynamic annual cycles: Aphaenogaster, Camponotus, Cataglyphis, Crematogaster, Formica, Harpagoxenus, Lasius, Lepisiota, Leptothorax, Manica, Myrmica, Plagiolepis, Ponera, Proformica and Tapinoma [18, 80, 96, 145-147, 149-151]. Analysis of the literature data from our conceptual positions allows us to classify the following species as endogenous-heterodynamic: Aphaenogaster subterranea [152], Camponotus herculeanus, C. ligniperda, C. noveboraceus, C. pennsylvanicus, C. vagus [105, 107, 153], Cataglyphis cursor [133-135], Crematogaster scutellaris [154-157], Formica sanguinea [158], F. ulkei [159], the genera Leptothorax and Temnothorax (with the exception of subtropical ones) [69, 75, 85, 91, 112], Myrmica rubra [82, 160-162], Plagiolepis pygmaea [103] and Odontomachus brunneus [143].

The gradual decrease of a colony capability to produce new eggs and to grow up non-diapausing larvae takes place during the summer season. At the same time, there is the increase of the bias for diapause as a consequence of the ongoing endogenous physiological and social processes. Moreover, the ant colony gradually acquires the sensitivity to the day length (to the photoperiod). The increasing photoperiodic sensitivity of a colony strongly changes the reaction to temperature. Because of these processes, at the end of the summer, the decrease of temperatures and the shortening of the day length (in some species only) contribute to the onset of diapause, thereby reducing the period of egg laying and larval development. The same impact of external factors to the colony's life cycle was found in all ant species that we studied $[80,96,146,163-165]$. So, the duration of a colony's annual cycle of brood rearing in nature is controlled both by an endogenous timer and by exogenous environmental cues, such as temperature and photoperiod (in some species). These environmental conditions adjust the date of diapause onset to the climatic features of a given year. 
Temperature control of diapause is the most universal in ants. The higher temperatures delay the onset of diapause both in larvae and adults, whereas the lower temperatures always accelerate the process of the beginning both in larvae and adults. On the contrary, photoperiodic control of diapause is unexpectedly uncommon among ants. For the first time, the photoperiodic responses were revealed in M. rubra and M. ruginodis [163]. It has been shown that the diapause in larvae and queen appeared more quickly when the day length decreased in the range from 16 to $13 \mathrm{~h}[163,164]$. The diapause both in queens and larvae ceased when inactive ant colonies in autumn condition were exposed to day lengths of $15 \mathrm{~h}$ [166]. Later on, Hand [167] and Brian [168] confirmed the presence of the reaction to photoperiodic conditions in M. rubra.

The subsequent extensive investigations nonetheless have shown that apart from Myrmica only few ant species used photoperiod as an ecological cue which controls all life processes in a colony: development, oviposition and diapause onset. We have found that photoperiodic conditions affected the induction of diapause only in Aphaenogaster sinensis [80] and Lepisiota semenovi [169]. Additionally, we have observed higher incidence of diapause in larvae under short-day conditions than in larvae under long-day conditions in Camponotus herculeanus, Leptothorax acervorum and Manica rubida. Thus, the genus Myrmica represents a rather curious exception among temperate ants since all Myrmica species studied so far possess clear-cut photoperiodic responses, which control the induction and termination of diapause $[149,150$, $163,164,170,171]$.

Thereby, the seasonal development of most ant species from temperate climate regions depends on inner timer in combination with environmental temperature, which triggers the onset of diapause. The environmental factors can modify the duration of the seasonal broodrearing cycle within broad range in most species of the genera Aphaenogaster, Crematogaster, Lasius, Myrmica and Tapinoma. For example, suboptimal temperatures of $17-20^{\circ} \mathrm{C}$ and short days vastly bring closer the beginning of diapause in larvae and queens of Myrmica rubra and $M$. ruginodis [163]. Whereas at long days and a temperature of $25^{\circ} \mathrm{C}$, egg laying and the development and pupation of rapid brood larvae continue for several months without interruption $[149,164]$.

The seasonal cycle of oviposition and development in other species is controlled predominantly by the endogenous mechanisms. In these ants, the moment of diapause onset depends only slightly on environmental conditions. Temperature hardly modifies the intrinsic length of the queens' oviposition period in all studied Formica species [96, 165]. The annual broodrearing cycle in Cataglyphis species and the species from subgenera Camponotus s. str. and Leptothorax s. str. is also relatively independent of the environment.

\section{The regulation of diapause in larvae}

The diapause of larvae in ants is facultative in most case, i.e. a given larva can either develop directly or fall into a diapause depending on the circumstances. Temperature can affect larval development and induce diapause both directly and through the nurse workers. Detailed studies performed on M. rubra have made it possible to prove that ant larvae themselves were not able to sensate the photoperiodic conditions in which they were placed $[172,173]$. 
Actually, the development of larvae was under the influence of workers whose physiological state and behavior strongly depended on the day length because they received the information about the photoperiodic conditions from the external environment. In laboratory experiments, we easily obtained the workers and larvae in alternative physiological states either by keeping the ant colonies under long-day conditions from the spring and by activating them with long-day photoperiods in autumn (getting of physiologically active, non-diapause individuals) or by exposing the ant colonies to the influence of short-day conditions during 1 month (getting of physiologically inactive, diapausing individuals). We have shown that non-diapause workers induced growth and pupation of summer larvae and interrupted the diapause of autumn larvae, while diapausing workers were incapable to support a high growth rate of larvae and forced them to fall into a diapause [13, 170]. We examined the characteristic features of social control by workers over larval development in several ant species and created experiments using workers and larvae in alternative physiological states. The experimental scheme included four sets: (1) spring state: physiologically active workers (after hibernation) with physiologically active larvae; (2) termination of larval diapause: physiologically active workers with diapausing larvae; (3) induction of larval diapause: diapausing workers with physiologically active larvae and (4) autumn state: diapausing workers with diapausing larvae.

The results of these experiments demonstrated that ant species studied fundamentally distinguished from each other [13-16, 170, 174]. In Camponotus herculeanus, C. japonicus and several Tetramorium species not overwintered physiologically inactive diapausing larvae, which were provided with food by spring physiologically active workers, developed rapidly and pupated within a short period, whereas overwintered larvae placed into the nests with autumn diapausing workers did not develop and pupate at all or only a few of them pupated sometimes. Thus, the workers of these ants exercise full control over the development and the diapause of their larvae. However, in Leptothorax acervorum, we found an entirely opposite situation: autumn workers could not prevent development of spring larvae and they all pupated. At the same time, overwintered workers stimulated the development of less than half of diapausing larvae. In Myrmica rubra, M. ruginodis, M. lobicornis and Lasius niger, we observed an intermediate situation: only some spring larvae pupated when fed by autumn workers, and also far from all autumn larvae finished the development under the care of spring workers.

Thus, the forms of social influence of workers on larval diapause are diverse in ants and range from nearly absolute control (in Camponotus and Tetramorium), when the physiological state of workers completely defines the fate of larvae, to rather weak effects when diapausing workers are unable to prevent the pupation of most of overwintered larvae, and spring workers are capable of inducing the development and pupation of only a few diapausing autumn larvae (in Leptothorax). In most species (Lasius, Myrmica), however, the intermediate variants of diapause control are realized. There is some evidence that Myrmica workers can manipulate the development of larvae via changing the intensity of tactile stimulation and the frequency of feedings $[12,13,170,174]$. Probably, in the cases when larvae hibernate at younger instars (as in Camponotus s. str.) and need a long period of growth to complete development, diapausing 
workers cannot provide them with the necessary food. At the same time, spring workers are able to effectively stimulate the development of young diapausing larvae. On the other hand, large larvae, overwintered in the last instar (as in Leptothorax), can finish the development even without receiving enough food from diapausing workers. However, the diapause of these larvae is deeper and more durable, and the spring workers cannot break it.

In many ant species with endogenous- and exogenous-heterodynamic seasonal cycles, the larvae fall into a diapause in the last larval instar. These diapausing larvae continue to feed and to grow slowly and can attain a significantly larger size before overwintering. This larval growth in diapause state is very important for the process of caste differentiation in Myrmica [86]. Continuing to increase in the size the diapausing larvae in reality do not develop progressively, as far as the differentiation and enlargement of their imaginal buds do not occur. Only these well-grown large diapausing larvae potentially may become the female reproductives in spring [86]. Subsequently, Plateaux [69] described the identical phenomenon for L. nylanderi. In accordance with the results of our studies, slow growth of larvae in diapause state is an attribute of the ant species from the genera Camponotus (some species), Crematogaster, Lasius, Lepisiota, Leptothorax, Manica, Messor, Monomorium, Myrmica, Solenopsis and Tetramorium. The physiological nature and types of diapause in ants are examined in the paper of Kipyatkov [18].

\section{Evolution of annual cycles of development in ants}

Problems of the origin and evolution of the diapause and seasonal cycles of insect development attracted the attention of many researchers (for example, see [175-177]). The main conclusion reached by most authors is that the evolution of seasonal adaptations occurs largely beyond direct connection with the phylogeny of taxa, and all the elements and parameters of seasonal development known to us, including the diapause itself, the types of cycles, photoperiodic reactions and other regulatory mechanisms, repeatedly, independently and in a variety of ways arise in the evolution of insects. One and the same goal of adapting to certain seasonal environmental conditions can be reached in a variety of ways by combining a whole range of known (or even not yet described) physiological mechanisms [176, 177]. Such a clearly expressed diversity of evolutionary solutions makes it very difficult to analyze the possible ways of the evolution of seasonal development cycles, even within not very large groups of organisms. Nevertheless, some authors proposed various specific sequences of evolutionary events to explain the origin and development of photoperiodic reactions and other physiological mechanisms controlling the diapause and other seasonal adaptations [175]. The most promising approach to the problem of the evolution of seasonal adaptations can be the identification of basic adaptation syndromes, for example, structural types of the annual cycles, diapause forms, ways of synchronizing the cycle with the seasonal rhythm of the climate, etc. Then, it may be productive to look for correlations between all these adaptations and possible ties with the specific environmental conditions in which they are realized and also to analyze the occurrence of the phenomena under study within different taxa. 
More and more data appear on the role of diapause in the regulation of the life cycles of insects in tropics. In these regions, the diapause does not always prove to be adapted specifically to the extreme conditions of the abiotic environment, but is often associated with seasonal variations in food availability, migration and reproduction processes. This makes it possible to speak with confidence about the tropical origin of the diapause in many insects $[70,176]$. Moreover, the winter hibernation of insects is a relatively recent evolutionary acquisition that arose only after the formation of a glacial climate on the Earth [44]. The available facts do not completely exclude the hypothesis of the possible occurrence of the diapause by the gradual deepening of the developmental delays that first arise exogenously under the direct influence of cold, dryness, lack of food or other unfavorable conditions. The diapause is a fairly simple adaptation from the point of view of the possibility of forming its regulatory hormonal mechanisms, and therefore it could arise in evolution many times and in different ways [176, 177].

Turning to the analysis of the main trends in the evolution of the annual developmental cycles in ants, two most important and closely related questions should be pointed out. First, it is the origin of different forms of diapause, and secondly, possible ways of forming of endogenousheterodynamic developmental cycles with obligate diapause. It should be borne in mind that the family Formicidae, in its evolutionary origin, is undoubtedly associated with the tropical regions of the Earth, where most of the species of ants live now. From tropical regions, these insects penetrated into zones with temperate climate, forming new species and taxa of higher rank $[2,63]$. Another interesting issue, namely the evolution of the structure of the seasonal cycles in ants during their distribution to the north, has been discussed in detail in a special article of V. E. Kipyatkov [88].

It is possible to imagine at least two possible ways of the origin of heterodynamic annual cycles in ants living in temperate and cold climatic zones.

\subsection{Subtropical (quasi-heterodynamic) path of evolution}

We suppose the possibility of direct adaptation of homodynamic species which penetrate from the tropical regions into subtropics and further into the zone with temperate climate and with cold enough winter. In this case, they do not form a real diapause, and at first acquire the ability to overwinter in the state of a quiescent (cold coma) but suffer from more or less strong mortality, i.e. quasi-heterodynamic seasonal cycles appears. The diapause evolves later and seasonal development becomes exogenously heterodynamic.

The reality of this path of evolution is almost unquestionable. It has been illustrated above by a number of examples of quasi-heterodynamic seasonal cycles, in particular, by the example of two Pheidole species studied experimentally. Some of the quasi-heterodynamic species (Linepithema humile, Solenopsis invicta, S. richteri) are known to have penetrated recently into areas with subtropical and temperate climate. They represent a magnificent model of the evolution of heterodynamic cycles, but practically were not investigated experimentally. It is completely unclear; for example, do the populations of $S$. invicta that penetrated far enough to the north in the USA, shape some kind of a diapause, or in winter the development delays because of a quiescent, like in the populations from subtropics? The same question applies to 
the populations of L. humile in Southern France. An experimental study of these ants, as model systems, would make it possible to test the possibility of quite quickly (over several decades) occurrence of a diapause in quasi-heterodynamic species.

Probably, quasi-heterodynamic annual cycles with the brood death in late autumn arise in the evolution of many homodynamic ants, which penetrate from tropics into subtropics and further into regions with a warm temperate climate. The nomadic ants Neivamyrmex on the north of its distribution area in the USA live in regions with a fairly cold winter. Investigations were conducted on N. nigrescens by Schneirela in the southeast of Arizona at altitudes of about $1660 \mathrm{~m}$ above sea level [31]. He has shown that in the autumn, when the nights became cold, these ants with nocturnal activity ceased foraging activity. The lack of food compelled the queen to stop egg laying, the workers destroyed the remaining brood and adult ants hibernated in a shelter. In the spring when the temperature rose, the queen started oviposition. When larvae appeared, the ant colony gradually restored the cycle of nomadic behavior and brood rearing typical for the summer period [31]. Schneirela assumed the presence of direct influence of temperature on the development of these ants. However, this idea was not confirmed by experiments.

The second real way of verification of our assumption is to study the species taxonomically close to exogenous-heterodynamic ants from the zone with warm temperate climate, but inhabiting subtropics and tropics. The most promising in this respect are the genera Monomorium and especially Tetramorium. All of the species of these genera, which we studied, inhabit the temperate climate zone and are exogenous-heterodynamic.

If the onset of a diapause and exogenous-heterodynamic development on the basis of quasiheterodynamic seasonal cycles seems quite plausible, then the possibility of further evolution in this direction toward the formation of endogenous-heterodynamic cycles with obligate diapause is far from obvious. We do not have at present any definitive evidence of the reality of such an evolution, but in our experiments we found distinct manifestations of endogenous regulation of development in most exogenous-heterodynamic species [144]. The possibilities of evolutionary transition from exogenous- to endogenous-heterodynamic development within the group of closely related species are indirectly confirmed by the following three examples.

Two closely related species of the genus Tapinoma from Turkmenistan were investigated in sufficient detail experimentally and under natural conditions. T. karavaievi is a species widespread in the plains of Central Asia. It does not rise to the mountains higher than $600 \mathrm{~m}$ above sea level, i.e. lives in a fairly warm temperate climate [136]. Almost in all parameters of the regulation of seasonal development, this species is exogenous-heterodynamic. In the most optimal temperature conditions, we observed almost non-stop development in its colonies. The diapause of larvae in T. karavaiev, as a rule, terminates when the temperature rises [144]. Nevertheless, the endogenous regulatory component was distinctly expressed in this species at lower temperatures, and under conditions of free temperature selection in the temperature gradient installation, we observed a smoothed spontaneous rhythm of development [145]. Another species studied, T. erraticum, is common in southern Europe and the Caucasus, and in Turkmenistan occurs only in the mountains, i.e. clearly gravitates toward a cooler climate 
than T. karavaievi [136]. Experiments have shown that T. erraticum belonged to the group of endogenous-heterodynamic species and had a very stable winter larval diapause, which could not be disturbed by a simple increase in temperature.

The second example is a pair of taxonomically related species of the genus Monomorium, M. kusnezovi and M. ruzskyi. Due to the existence of significant geographical variability in morphology for a long time, many researchers have combined these ants into one species under different names and confused them [136]. The gradual accumulation of collection materials made it possible to find out that everywhere on the plains of Central Asia there is one variegated in color species, $M$. kusnezovi. Its mountain populations differ from the desert ones not only in smaller sizes and dark colors, but also in some peculiarities of biology [63]. Later, large differences between the queens of these two forms were found and the mountain form was described as M. ruzskyi [136].

Our observations have shown that M. kusnezovi and M. ruzskyi often met together in the foothills and lowlands of the Kopetdag. However, despite the taxonomic proximity of these two species, their annual cycles differ significantly. M. kusnezovi is quasi-heterodynamic, i.e. the diapause of the brood and the reproductive diapause of queens are absent, so eggs and larvae of all ages remain in the nest during the winter and a significant part of them perish. At the same time, the annual cycle of M. ruzskyi is of Myrmica type, i.e. it is endogenousheterodynamic and is characterized by a fairly stable diapause in larvae of the last (third) instar and in queens. Therefore, in the colonies of this species, only the larvae of the last instar hibernate, and they are always numerous. Thus, the features of the structure and regulation of the annual cycle make it possible to differentiate these closely related species no worse than the morphology of their queens.

We studied two Camponotus species, C. xerxes and C. aethiops, which belonged to the subgenus Tanaemyrmex, but differed dramatically in regulation of seasonal development. C. aethiops possesses an obligate, very stable diapause and endogenous-heterodynamic regulation of the annual cycle, while in C. xerxes there is an unstable diapause and mainly exogenous regulation. At a temperature of $25-27^{\circ} \mathrm{C}$, we observed continuous development in the colonies of C. xerxes for more than 2 years. These differences are obviously due to the fact that $C$. aethiops lives in a colder climate (Central and Southern Europe, Crimea, Caucasus and mountains of Central Asia) than C. xerxes (the desert plains of Afghanistan, Iran and Turkmenistan).

\subsection{Tropical (preadaptational) path of evolution}

Extremely few examples of heterodynamic annual cycles in tropical ants allow us to assume that such species, already possessing diapause (preadaptation), could probably easily penetrate into subtropics and further into the temperate climate zone, using the ability to form a diapause for experiencing a cold winter. The causes for diapause emergence in tropical ants can be diverse. For example, it can be the necessity for survival during the arid or excessively wet seasons of a year, during the periods of shortage or inability to obtain food, etc. It is also possible that the ability to diapause arose as a way of solving internal problems for the colony related to the regulation of development, the processes of caste differentiation and reproduction. 
Moreover, in tropics, both exogenous and endogenous mechanisms of diapause regulation could be formed, which under the new conditions of a temperate climate, and could be used to synchronize the onset of a diapause with the beginning of a cold season of a year.

Unfortunately, this scheme is almost entirely speculative, first of all, because tropical species with heterodynamic annual cycles have not been investigated experimentally so far, and we know absolutely nothing about the prevalence and nature of diapause in tropical ants. The only argument indirectly confirming the possibility of the tropical origin of heterodynamic annual development in many ants is the rather wide prevalence of endogenous-heterodynamic cycles with obligate diapause among ants inhabiting subtropical and warm temperate climate zone. Among the 39 species of ants from Turkmenistan and the southern coast of the Crimea which we experimentally studied, 18 (46\%) are endogenous-heterodynamic. An analysis of a few works, in which at least the simplest laboratory experiments were carried out, allows us to classify as endogenous-heterodynamic four more species from the zone with warm temperate and subtropical climate: Plagiolepis pygmaea [103], Camponotus vagus [107], Temnothorax monjanzei [74] and T. melas [75]. Are we correct to assert that in all these ants, the predominantly endogenous regulation of the annual cycle with the obligate diapause has evolved here in areas with a very warm or subtropical climate, or is it wiser to think that it originated in tropical ancestors of some of these species at least? The answer to this question is currently not possible due to lack of sufficient evidence.

\subsection{Taxonomic position and seasonal adaptations}

An example of close relationship between taxonomic position and seasonal adaptations is the Formicini tribe. All species studied use the strategy of concentrated brood rearing and are endogenous-heterodynamic with the obligate and very stable diapause of queens and workers and the apparent dominance of endogenous regulatory mechanisms. Probably, such a system of seasonal adaptations evolved already in the ancestors of this tribe.

All studied species of the genus Myrmica have a very similar structure of the seasonal development cycle [178, 179] and, according to our experiments, have photoperiodic regulation of a diapause rarely seen in other ants [18]. We have experimentally investigated the seasonal development of three species of the subgenus Camponotus s. str., C. herculeanus, C. japonicus and C. ligniperda and found almost complete similarity between them in all respects: endogenousheterodynamic regulation, obligate and very stable diapause of queens and larvae, the same overwintering stages (second instar larvae) and, finally, absolute control by workers over the onset and cessation of larval diapause [16]. According to available literature data, C. vagus from the same subgenus has identical characteristics of the seasonal cycle [107]. Finally, all species of the genus Tetramorium, which we studied, are distinguished by exogenous-heterodynamic regulation of seasonal development and temperature-unstable diapause.

Other examples relate to fairly definite correlations between taxonomic position and overwintering stages in a number of ants genera. In all species of Leptothorax and Messor, larvae diapause and overwinter mainly in the last two instars; in Myrmica and Tetramorium, in the last instar, obligatory; in Plagiolepis, in the first three instars and in Lasius, in all instars. 
Finally, all Aphaenogaster species studied so far do not have a diapause of queens and therefore hibernate with eggs and larvae in all instars. At the same time, directly opposite situations are known, when closely related ants have completely different seasonal adaptations. They are already mentioned above when comparing the following pairs of species: T. karavaievi-T. erraticum, M. kusnezovi-M. ruzskyi and C. xerxes-C. aethiops.

Thus, it can be argued that in the evolution of ants, correlations could arise between the nature of seasonal adaptations and the phylogeny of taxa, but no less common are the cases of the absence of such connections, i.e. the appearance of significant differences in the structure and regulation of the annual cycle between related species and, on the contrary, the parallel and independent formation of very similar adaptations in different phylogenetic branches.

\section{Conclusions}

1. Most tropical ants demonstrate homodynamic development. They do not exhibit any developmental delays and all-year round the ontogenetic stages from egg to pupa exist in their nests. Some of the quasi-heterodynamic species have permeated into the regions with warm temperate climate but a true diapause did not evolve. In these species, the brood development stops only at temperatures falling below the developmental threshold (consecutive dormancy). So, the ants spend the winter in the state of a quiescent (cold coma), while more or less high mortality rates are observed in their colonies. Most temperate and all boreal climate ants are true heterodynamic. They manifest a true deep winter diapause (prospective dormancy) in their annual cycle.

2. Heterodynamic ants use two main seasonal strategies with respect to brood rearing. The ants are more likely to follow the strategy of prolonged brood rearing. It is distinguished by the following features: (1) larval diapause is facultative and controlled by environmental (temperature, photoperiod) and social (worker care, queen influence, pheromones, etc.) factors; (2) only some larvae develop from egg to pupa within the same summer season without overwintering (this rapid brood, or summer brood, yields only workers); (3) a large proportion of larvae delay their development, continue to grow in autumn, overwinter in diapause and pupate the next summer (this slow brood, or winter brood, yields both workers and alates).

3. The strategy of concentrated brood rearing is distinguished by the following features: (1) larvae have no dormancy and complete their development during the summer; (2) the development of all brood stages is thus restricted to the growing season; (3) only queens and workers are able to undergo diapause and overwinter; (4) the colony thus passes the winter without brood. This strategy, however, is not the most common.

4. The forms of dormancy which were found in ants extend from elementary quiescence to deep diapause. In exogenous-heterodynamic species, the diapause is optional for larvae and queens. The diapause occurs as a result of a direct reaction to temperature decline in the autumn but at a moment when the temperatures still exceed the developmental threshold. 
5. On the contrary in endogenous-heterodynamic ant species, the diapause is compulsory for the colony and occurs eventually under any conditions. Two main factors restrict and control the internal brood-rearing cycle in these species. They are the endogenous timer and environmental conditions, temperature and photoperiod (in some species). But environmental cues can only regulate in some degree the moment of the onset of diapause by accelerating or delaying this event. All cold climate ants have adult diapause, so that their queens and workers are capable for overwintering. Queens and some workers experience diapause several times in their life. On the contrary, the ability of larvae to undergo diapause is not universal in ants. This is a major factor in seasonal cycle evolution in these insects.

6. The diapause of larvae in ants is facultative in most case. Temperature can affect larval development and induce diapause both directly and through the nurse workers. The larvae appeared to be entirely insensitive to the direct influence of photoperiods. The forms of social impact on larval diapause by workers are diverse in ants and range from nearly absolute control when the physiological state of workers completely defines the fate of larvae, to rather weak effects when in experimental conditions diapausing workers are unable to prevent the development of most overwintered larvae, and spring workers are capable to induce pupation of only a few diapausing autumn larvae.

7. We can conclude that the similar seasonal adaptations could arise in ant evolution independently many times and usually are not tightly bound to the taxonomic position of species. Nevertheless, several examples of certain seasonal cycle traits clearly confined to specific ant taxa have been found.

\section{Acknowledgements}

I am very grateful to students and members of the Department of Entomology, St. Petersburg State University, who participated in these long-term investigations in different years. This work was supported by grants from European Union INTAS program (94-2072), Russian Foundation of Basic Research (97-04-48987, 00-04-49003, 03-04-48854, 06-04-49383), Federal Program "Universities of Russia" (07.01.026, 07.01.327) and the Council for Grants from the President of the Russian Federation and for State Support of Leading Scientific Schools (0015-97934, 2234.2003.4, 7130.2006.4).

\section{Author details}

Elena B. Lopatina ${ }^{+}$

Address all correspondence to: elena.lopatina@gmail.com

Department of Entomology, Saint Petersburg State University, Russian Federation

† This review is dedicated to the memory of Professor V.E. Kipyatkov (1949-2012) who devoted his life to the study of seasonal cycles of development in ants. 


\section{References}

[1] Brian M. Social Insects. Ecology and Behavioural Biology. London and New York: Chapman and Hall; 1983. 377 p. DOI: 10.1007/978-94-009-5915-6

[2] Hölldobler B, Wilson E. The Ants. Cambridge, MA: Belknap Press; 1990. 732 p

[3] Yozhikov I. On the comparative ecology of social insects. Trudy Otdeleniya Ecologii Timiryazevskogo Nauchno-Issledovatel'skogo Instituta. 1929;4(1):7-24 (in Russian)

[4] Headley A. Population studies of two species of ants, Leptothorax longispinosus Roger and Leptothorax curvispinosus Mayr. Annals of the Entomological Society of America. 1943;36:743-753. DOI: 10.1093/aesa/36.4.743

[5] Headley A. A population study of the ant Aphaenogaster fulva ssp. aquia Buckley (Hymenoptera, Formicidae). Annals of the Entomological Society of America. 1949;42:265-272. DOI: $10.1093 /$ aesa/42.3.265

[6] Talbot M. Population studies of the ant Myrmica schencki ssp. emeryana Forel. Annals of the Entomological Society of America. 1945;38:365-372. DOI: 10.1093/aesa/38.3.365

[7] Eidmann H. Die überwinterung der Ameisen. Zeitschrift für Morphologie und Ökologie der Tiere. 1943;39:217-275. DOI: http://www.jstor.org/stable/43261901

[8] Brian M. The synchronisation of colony and climatic cycles. In: Proceedings of the 8th International Congress of the International Union for the Study of Social Insects, September 5-10, 1977, Wageningen. 1977. pp. 202-206

[9] Brian M. Regulation of sexual production in an ant society. In: Colloques Internationaux du Centre National de la Recherche Scientifique, Paris: 1967. No 173 Ed. 1968. pp. $61-74$

[10] Brian M. Ants. London: Collins; 1977. 223 p

[11] Kipyatkov V. Distantly perceiving primer pheromone controls the diapause termination in the ant, Myrmica rubra L. (Hymenoptera, Formicidae). Journal of Evolutionary Biochemistry and Physiology 2001;37:405-416. DOI: 10.1023/A:1012926929059

[12] Kipyatkov V, Lopatina E. Behavior of worker ants during the feeding of larvae in Myrmica rubra (Hymenoptera, Formicidae). Zoologicheskii Zhurnal. 1989;68:50-59 (in Russian with English summary)

[13] Kipyatkov V, Lopatina E. Quantitative study of the behavior of the ant Myrmica rubra L. (Hymenoptera, Formicidae) relative to photoperiodic regulation of larval development. Entomologicheskoe Obozrenie. 1989;68:251-261 (in Russian with English summary; English translation in: Entomological Review. 1990;69:31-41)

[14] Kipyatkov V, Lopatina E, Pinegin A. Influence of workers and the queen on the onset and termination of the larval diapause in the ant Lasius niger (L.) (Hymenoptera, Formicidae). Entomologicheskoe Obozrenie. 1996;75:507-515 (in Russian with English summary; English translation in: Entomological Review. 1996;76:514-520) 
[15] Kipyatkov V, Lopatina E, Pinegin A. Social regulation of development and diapause in the ant Leptothorax acervorum (Hymenoptera, Formicidae). Entomological Review. $1997 ; 77: 248-255$

[16] Lopatina E, Kipyatkov V. Behavioural and physiological control by workers over the development of larvae in the seasonal life cycle of ant colony. In: Programme and Abstracts of the International Symposium "Life Cycles in Social Insects: Behavioural, Ecological and Evolutionary Approach" September 22-27, 2003; St. Petersburg, Russia: St. Petersburg University Press; 2003. pp. 40-42

[17] Bourke A, Franks N. Social evolution in ants. In: Krebs J, Clutton-Brock T, series editor. Monographs in Behavior and Ecology. Princeton, New Jersey: Princeton University Press; 1995. ix+529 p. DOI: 10.1046/j.1420-9101.1996.9061032.x

[18] Kipyatkov V. Seasonal life cycles and the forms of dormancy in ants (Hymenoptera, Formicoidea). Acta Societatis Zoologicae Bohemicae. 2001;65:211-238

[19] Roubaud E. Étude sur le sommeil d'hiver pre-imaginal des muscides. Bulletin Biologique De La France Et De La Belgique. 1922;56:455-544

[20] Roubaud E. Sommeil d'hiver cédant à l'hiver chez les larves et nymphes de muscides. Comptes Rendus de l'Académie des Sciences. 1922;174:964-966

[21] Roubaud E. La réactivation climatique et la distribution géographique des espèces. Compte Rendu de la Association Française pour l'Avancement des Sciences. 1925;48: 982-986

[22] Ackonor J. The nest and nesting habits of the ant Cataulacus guineensis F. Smith (Hymenoptera, Formicidae) in a Ghanaian cocoa farm. Insect Science and its Application. 1983;4:267-283. DOI: 10.1017/S174275840000126

[23] Basalingappa S, Kareddy V, Matapathi S, Gandhi M. Population studies on the ant, Camponotus sericeus Fabricius. Comparative Physiology and Ecology. 1986;11:32-37

[24] Basalingappa S, Kareddy V, Matapathi S, Gandhi M. Colony-founding and life-cycle in the ant Camponotus sericeus Fabricius (Hymenoptera: Formicidae). Uttar Pradesh Journal of Zoology. 1989;9:73-83

[25] Braun U, Hölldobler B, Peeters C. Colony life cycle and sex ratio of the ant Paltothyreus tarsatus in Ivory Coast. In: Lenoir A, Arnold G, Lepage M, editors. Les Insectes Sociaux. 12th Congress of the International Union for the Study of Social Insects, Paris, Sorbonne, August 21-27, Sorbonne, Paris 1994. Paris: Université Paris Nord; 1994. p. 330

[26] Baker G. The seasonal life cycle of Anoplolepis longipes (Jerdon) (Hymenoptera: Formicidae) in a cacao plantation and under brushed rain forest in the northern district of Papua New Guinea. Insectes Sociaux. 1976;23:253-261. DOI: 10.1007/BF02283900

[27] Haines I, Haines J. Colony structure, seasonality and food requirements of the crazy ant, Anoplolepis longipes (Jerd.), in the Seychelles. Ecological Entomology. 1978;3:109-118. DOI: 10.1111/j.1365-2311.1978.tb00909.x 
[28] Curtis B. Observations on the natural history and behaviour of the dune ant, Camponotus detritus Emery, in the central Namib Desert. Madoqua. 1985;14:279-289

[29] Ward P. Ecology and life history of the Rhytidoponera impressa group (Hymenoptera: Formicidae). II. Colony origin, seasonal cycles, and reproduction. Psyche 1981;88:109126. DOI: $10.1155 / 1981 / 39593$

[30] Benois A. Incidence des facteurs écologiques sur le cycle annuel et l'activité saisonnière de la fourmi d'Argentine, Iridomyrmex humilis Mayr (Hymenoptera, Formicidae), dans la région d'Antibes. Insectes Sociaux. 1973;20:267-295. DOI: 10.1007/BF02223196

[31] Schneirla T. Army ants. In: Topoff HR, editor. A Study in Social Organization. San Francisco: W. H. Freeman and Company; 1971. XX+349 p

[32] Gotwald Jr W. Army ants. In: Hermann HR, editor. Social Insects Vol. 4. New York: Academic Press; 1982. pp. 157-254

[33] Rettenmeyer C, Chadab-Crepet R, Naumann M, Morales L. Comparative foraging by Neotropical army ants. In: Jaisson P, editor. Social Insects in the Tropics. Proceedings of the First International Symposium. Vol. 2. Paris: Presses de l'Université Paris XIII; 1983. pp. 59-73

[34] Terron G. Évolution des colonies de Tetraponera anthracina Santschi (Formicidae, Pseudomyrmecinae) avec reines. Bulletin Biologique de la France et de la Belgique. 1977;111:115-181

[35] Peacock A. Studies in Pharaoh's ant, Monomorium pharaonis (L.). 2. Methods of recording observations on artificial colonies. Entomologist's Monthly Magazine. 1950;86:129-135

[36] Peacock A. Studies in Pharaoh's ant, Monomorium pharaonis (L.). 4. Egg-production. Entomologist's Monthly Magazine. 1950;86:294-298

[37] Peacock A, Baxter A. Studies in Pharaoh's ant, Monomorium pharaonis (L.). 1. The rearing of artificial colonies. Entomologist's Monthly Magazine. 1949;85:256-260

[38] Peacock A, Baxter A. Studies in Pharaoh's ant, Monomorium pharaonis (L.). 3. Life history. Entomologist's Monthly Magazine. 1950;86:171-178

[39] Peacock A, Waterhouse F, Baxter A. Studies in Pharaoh's ant, Monomorium pharaonis (L.). 10. Viability in regard to temperature and humidity. Entomologist's Monthly Magazine. 1955;91:37-42

[40] Petersen Braun M. Untersuchungen zur sozialen Organisation der Pharaoameise Monomorium pharaonis (L.) (Hymenoptera, Formicidae). I. Der Brutzyklus und seine Steuerung durch populationseigene Faktoren. Insectes Sociaux. 1975;22:269-291. DOI: 10.1007/BF02223077

[41] Petersen-Braun M. Studies on the endogenous breeding cycle in Monomorium pharaonis L. (Formicidae). In: Proceedings of the 8th International Congress of the International 
Union for the Study of Social Insects, September 5-10, 1977, Wageningen; 1977. pp. 211-212

[42] Kipyatkov V, Lopatina E. A Comparative study of thermal reaction norms for development in ants. Entomological Science. 2015;18:174-192. DOI: 10.1111/ens.12098

[43] Berndt K-P, Eichler W. Die Pharaoameise, Monomorium pharaonis (L.) (Hym., Myrmicidae). Mitteilungen aus dem Zoologischen Museum in Berlin. 1987;63:183-186. DOI: 10.1002/mmnz.19870630102

[44] Leather S, Walters K, Bale J. The Ecology of Insect Overwintering. Cambridge: University Press; 1993. X+255 p. DOI: 10.1017/CBO9780511525834

[45] Baldridge R, DeGraffenried J. Pseudomyrmex sp. (Hymenoptera: Formicidae) nesting in mimosa (Albizia julibrissin Dur.). The Southwestern Naturalist. 1988;33:112-114. DOI: $10.2307 / 3672102$

[46] Rissing S. Annual cycles in worker size of the seed-harvester ant Veromessor pergandei (Hymenoptera: Formicidae). Behavioral Ecology and Sociobiology. 1987;20;117-124. DOI: http://www.jstor.org/stable/4599998

[47] Lennartz F. Modes of dispersal of Solenopsis invicta from Brazil into the continental United States, a study in spatial diffusion [thesis]. University of Florida; 1973. 242 p

[48] Lofgren C, Banks W, Glancey B. Biology and control of imported fire ants. Annual Review of Entomology. 1975;20:1-30. DOI: 10.1146/annurev.en.20.010175.000245

[49] Lofgren C. History of imported fire ants in the United States. In: Lofgren CS, Vander Meer RK, editors. Fire Ants and Leaf Cutting Ants: Biology and Management. Boulder, CO: Westview Press; 1986. pp. 36-47

[50] Shoemaker D, Ross K, Arnold M. Development of RAPD markers in two introduced fire ants, Solenopsis invicta and S. richteri, and their application to the study of a hybrid zone. Molecular Ecology. 1994;3:531-539. DOI: 10.1111/j.1365-294X.1994.tb00084.x

[51] Markin G, Dillier J. The seasonal life cycle of the imported fire ant, Solenopsis saevissima richteri, on the Gulf coast of Mississippi. Annals of the Entomological Society of America. 1971;64:562-565. DOI: 10.1093/aesa/64.3.537

[52] Horton P, Hays S. Occurrence of brood stages and adult castes in field colonies of the red imported fire ant in South Carolina. Environmental Entomology. 1974;3:656-658. DOI: 10.1093/ee/3.4.656

[53] Markin G, O'Neal J, Dillier J, Collins H. Regional variation in the seasonal activity of the imported fire ant, Solenopsis saevissima richteri. Environmental Entomology. 1974;3:446452. DOI: $10.1093 /$ ee/3.3.446

[54] Porter S. Impact of temperature on colony growth and developmental rates of the ant, Solenopsis invicta. Journal of Insect Physiology. 1988;34:1127-1133. DOI: 10.1016/ 0022-1910(88)90215-6 
[55] Morrill W. Overwinter survival of the red imported fire ant in Central Georgia. Environmental Entomology. 1977;6:50-52. DOI: 10.1093/ee/6.1.50

[56] Markin G. The seasonal life cycle of the argentine ant, Iridomyrmex humilis (Hymenoptera: Formicidae), in South-California. Annals of the Entomological Society of America. 1970; 63:1238-1242. DOI: 10.1093/aesa/63.5.1238

[57] Vargo E, Passera L. Gyne development in the argentine ant Iridomyrmex humilis: Role of overwintering and queen control. Physiological Entomology. 1992;17:193-201. DOI: 10.1111/j.1365-3032.1992.tb01199.x

[58] Talbot M. Population studies of ants in a Missouri woodland. Insectes Sociaux. 1957;4:375-384. DOI: 10.1007/BF02224157

[59] MacKay W. A comparison of the nest phenologies of three species of Pogonomyrmex harvester ants (Hymenoptera: Formicidae). Psyche. 1981;88:25-74. DOI: 10.1155/1981/78635

[60] Talbot M. Population studies of the ant, Prenolepis imparis say. Ecology. 1943;24:31-44. DOI: $10.2307 / 1929858$

[61] Talbot M. Response of the ant Prenolepis imparis say to temperature and humidity changes. Ecology. 1943;24:345-352. DOI: 10.2307/1930536

[62] Tschinkel W. Seasonal life history and nest architecture of a winter-active ant, Prenolepis impairs. Insectes Sociaux. 1987;34:143-164. DOI: 10.1007/BF02224081

[63] Dlusskiy G. Murav'i Pustyn' [Ants of Deserts]. Moscow: Nauka; 1981. 230 p. (in Russian)

[64] Kupyanskaya A. Murav'i (Hymenoptera, Formicidae) Dal'nego Vostoka SSSR [Ants (Hymenoptera, Formicidae) of the USSR Far East]. Vladivostok: Far East Branch of Acad. Sci. USSR; 1990. 258 p. (in Russian)

[65] Passera L. Production des soldats dans les sociétés sortant d'hibernation chez la Fourmi Pheidole pallidula (Nyl.) (Formicidae Myrmicinae). Insectes Sociaux. 1977;24:131-146. DOI: $10.1007 / \mathrm{BF} 02227167$

[66] Passera L. La ponte d'oeufs préorientés chez la fourmi Pheidole pallidula (Nyl.) (Hymenoptera: Formicidae). Insectes Sociaux. 1980;27:79-95. DOI: 10.1007/BF02224522

[67] Passera L, Suzzoni JP. Le rôle de la reine de Pheidole pallidula (Nyl.) (Hymenoptera, Fromicidae) dans la sexualisation du couvain après traitement par l'hormone juvénile. Insectes Sociaux. 1979;26:343-353. DOI: 10.1007/BF02223553

[68] Murdock TC, Tschinkel WR. The life history and seasonal cycle of the ant, Pheidole morrisi Forel, as revealed by wax casting. Insectes Sociaux. 2015;62:265-280. DOI: 10.1007/ s00040-015-0403-9

[69] Plateaux L. Sur le polymorphisme social de la Fourmi Leptothorax nylanderi (Förster). I. - Morphologie et biologie comparées des castes. Annales des Sciences Naturelles. (Zoologie). 1970;12:373-478 
[70] Denlinger D. Dormancy in tropical insects. Annual Review of Entomology. 1986;31:239264. DOI: 10.1146/annurev.en.31.010186.001323

[71] Ito F, Higashi S, Maeta Y. Growth and development of Camponotus (Paramyrmamblys) kiusiuensis Santschi colonies (Hymenoptera Formicidae). Insectes Sociaux. 1988;35:251261. DOI: $10.1007 / \mathrm{BF} 02224058$

[72] Satoh T. Comparisons between two apparently distinct forms of Camponotus nawai Ito (Hymenoptera, Formicidae). Insectes Sociaux. 1989;36:277-292. DOI: 10.1007/BF02224881

[73] Masuko K. Behavior and ecology of the enigmatic ant Leptanilla japonica Baroni Urbani (Hymenoptera: Formicidae: Leptanillinae). Insectes Sociaux. 1990;37:31-57. DOI: 10.1007/ BF02223813

[74] Cagniant H. Description de Leptothorax monjanzei n. sp. d'Algérie. Bulletin de la Société Entomologique de France. 1968;73:83-90

[75] Espadaler X, Plateaux L, Casevitz-Weulersse J. Leptothorax melas, n. sp., de Corse notes écologiques et biologiques [Hymenoptera, Formicidae]. Revue Française d'Entomologie. 1984;6:123-132

[76] Herbers J. The population biology of Tapinoma minutum (Hymenoptera: Formicidae) in Australia. Insectes Sociaux. 1991;38:195-204. DOI: 10.1007/BF01240969

[77] Chen Y, Tang J. Studies on colony structure and lifecycle of the spinned ant Polyrhachis vicina Roger. Zoological Research. 1989;10:57-63

[78] Chen Y, Tang J. Daily rhythm and seasonal activity of the weaver ant, Polyrhachis vicina. In: Proceedings of 19th International Congress of Entomology; 28 June-4 July 1992; Beijing, China. 1992. p. 241

[79] Laskis K, Tschinkel W. The seasonal natural history of the ant, Dolichoderus mariae, in northern Florida. Journal of Insect Science. 2009;9(2):26. DOI: 10.1673/031.009.0201

[80] Kipyatkov V, Lopatina E. Seasonal development of Aphaenogaster sinensis in the South Primorye: A new type of seasonal cycles in ants. Zoologicheskii Zhurnal. 1990;69:6979 (in Russian with English summary, English translation in: Entomological Review. 1990;69:72-81)

[81] Brian M. Summer population changes in colonies of the ant Myrmica. Physiologia Comparata et Oecologia. 1951;2:248-262

[82] Brian M. Serial organization of brood in Myrmica. Insectes Sociaux. 1957;4:191-210. DOI: 10.1007/BF02222153

[83] Traniello J. Population structure and social organization in the primitive ant Amblyopone pallipes (Hymenoptera: Formicidae). Psyche. 1982;89:65-80. DOI: 10.1155/1982/79349

[84] Peakin G. The growth and development of the overwintering larvae in the ant Lasius flavus (Hymenoptera, Formicidae). Journal of Zoology. 1985;205:179-189. DOI: 10.1111/ j.1469-7998.1985.tb03527.x 
[85] Plateaux L. Sur le polymorphisme social de la Fourmi Leptothorax nylanderi (Förster). II. - Activité des ouvrières et déterminisme des castes. Annales des Sciences Naturelles (Zoologie). 1971;13:1-90

[86] Brian M. Studies of caste differentiation in Myrmica rubra L. 3. Larval dormancy, winter size and vernalisation. Insectes Sociaux. 1955;2:85-114. DOI: 10.1007/BF02224096

[87] Wilson E. The Insect Societies. Cambridge, MA: Belknap Press; 1971.548 p

[88] Kipyatkov V. The evolution of seasonal cycles in cold-temperate and boreal ants: Patterns and constraints. In: Kipyatkov V, editor. Life Cycles in Social Insects: Behaviour, Ecology and Evolution. St. Petersburg: St. Petersburg University Press; 2006. pp. 63-84

[89] Martin P. Cycle annuel de Leptothorax unifasciatus (Latr.) elevé en laboratoire. Résultats preliminaries. Actes des Colloques Insectes Sociaux. 1988;4:169-175

[90] Suzzoni J-P, Grimal A, Passera L. Modalité et cinétique du développement larvaire chez la fourmi Camponotus aethiops Latr. Bulletin de la Société Zoologique de France. 1986;111:113-121

[91] Buschinger A. The role of daily temperature rhythms in brood development of ants of the tribe Leptothoracini (Hymenoptera; Formicidae). In: Wieser W, editor. Effects of Temperature on Ectothermic Organisms. Berlin: Springer Verlag; 1973. pp. 229-232. DOI: 10.1007/978-3-642-65703-0

[92] Espadaler X, Du Merle P, Plateaux L. Redescription de Leptothorax grouvellei Bondroit, 1918. Notes biologiques et écologiques (Hymenoptera, Formicidae). Insectes Sociaux. 1983;30:274-286. DOI: 10.1007/BF02223985

[93] Brian M. The growth and development of colonies of the ant Myrmica. Insectes Sociaux. 1957;4:177-190. DOI: 10.1007/BF02222152

[94] Danks H. Arctic Arthropods: A Review of Systematics and Ecology with Particular Reference to the North American Fauna. Ottawa: Entomological Society of Canada; 1981. vii+608 p

[95] Danks H. Life cycles in polar arthropods - Flexible or programmed? European Journal of Entomology. 1999;96:83-102

[96] Kipyatkov V, Lopatina E. The regulation of annual cycle of development in the ants of the subgenus Serviformica (Hymenoptera, Formicidae). In: Kipyatkov VE, Editor. Proceedings of the Colloquia on Social Insects. Vol. 2. Russian-speaking Section of the IUSSI, Socium: St. Petersburg; 1993. pp. 49-60

[97] Talbot M. Populations and hibernating conditions of the ant Aphaenogaster (Attomyrma) rudis Emery (Hymenoptera: Formicidae). Annals of the Entomological Society of America. 1951;44:302-307. DOI: 10.1093/aesa/44.3.302

[98] Mizutani A, Imamura S. Population and nest structure in the ant Aphaenogaster japonica Forel, in Sapporo, Japan. Kontyû. 1980;48:241-247 
[99] Thomas M. Seasonality and colony-size effects on the life-history characteristics of Rhytidoponera metallica in temperate South-Eastern Australia. Australian Journal of Zoology. 2003;51:551-567. DOI: 10.1071/ZO03037

[100] Passera L, Dejean A. Étude de la ponte à basse température de Temnothorax recedens (Nyl.) et de quelques espèces du genre Leptothorax (Formicidae, Myrmicinae). Insectes Sociaux. 1974;21:407-415. DOI: 10.1007/BF02331568

[101] Talbot M. Population studies of the slave-making ant Leptothorax duloticus and its slave, Leptothorax curvispinosus. Ecology. 1957;38:449-456. DOI: 10.2307/1929889

[102] Passera L. Le cycle évolutif de la Fourmi Plagiolepis pygmaea Latr. (Hym. Form. Formicidae). Insectes Sociaux. 1963;10:59-70. DOI: 10.1007/BF02223522

[103] Passera L. Biologie de la reproduction chez Plagiolepis pygmaea Latreille et ses deux parasites sociaux Plagiolepis grassei Le Masne et Passera et Plagiolepis xene Stärcke (Hymenoptera, Formicidae). Annales des Sciences Naturelles-Zoologie. 1969;11:327-482

[104] Sanders C. The biology of carpenter ants in New Brunswick. Canadian Entomologist. 1964;96:894-909. DOI: 10.4039/Ent96894-6

[105] Sanders C. Seasonal and daily activity patterns of carpenter ants (Camponotus spp. ) in northwestern Ontario (Hymenoptera: Formicidae). Canadian Entomologist. 1972; 104:1681-1687. DOI: 10.4039/Ent1041681-11

[106] Delage B. Recherches sur les fourmis moissonneuses du Bassin Aquitain: écologie et biologie. Bulletin Biologique de la France et de la Belgique. 1968;102:315-367

[107] Benois A. Évolution du couvain et cycle annuel de Camponotus vagus Scop (=pubescens Fabr.) (Hymenoptera, Formicidae) dans la région d'Antibes. Annales de Zoologie Ecologie Animale. 1972;4:325-351

[108] Dartigues D, Passera L. Polymorphisme larvaire et chronologie de l'apparition des castes femelles chez Camponotus aethiops Latreille (Hymenoptera, Formicidae). Bulletin de la Société Zoologique de France. 1979;104:197-207

[109] Cammaerts M-C. Étude démographique annuelle des sociétés de Myrmica rubra L. des environs de Bruxelles. Insectes Sociaux. 1977;24:147-161. DOI: 10.1007/BF02227168

[110] Ichinose K. Annual life cycle of Paratrechina flavipes (Hymenoptera, Formicidae) in the Tomakomai experiment Forest, southern Hokkaido. Kontyû. 1987;55:9-20

[111] Plateaux L. Dynamique des sociétés de la fourmi Leptothorax nylanderi (Förster). Biology and Ecology (Méditerranée). 1980;7:195-196

[112] Plateaux L. Comparaison des cycles saisonniers, des durées des sociétés et des productions des trois espèces de fourmis Leptothorax (Myrafant) du groupe nylanderi. Actes des Colloques Insectes Sociaux. 1986;3:221-234 
[113] Tohmé H, Tohmé G. La fondation de la société, le cycle biologique et ses variations chez Messor syriacus (Santschi) (Hym. Formicoïdea). Comptes Rendus de l'Académie des Sciences. Paris, Series D. 1980;290:1377-1379

[114] Tohmé G, Tohmé H. Le cycle biologique de Messor incorruptus (Ruzsky) (Hym. Formicoïdea). Corrélation entre l'espace disponible pour cette société de Fourmis et la productivité de celle-ci. Comptes Rendus de l'Académie des Sciences. Paris, Series III. 1982;294:115-118

[115] Cerdan P, Délye G. La fondation et les premières années du développement de la société de Messor barbarus (L.) (Hymenoptera, Formicidae). Comptes Rendus de l'Académie des Sciences. Paris. 1987;305:31-34

[116] Cerdan P, Délye G. L'hivernage et la ponte des femelles fondatrices de Messor barbarus (L.) (Hymenoptera Formicidae). Comptes Rendus de l'Académie des Sciences. Paris. 1990;310:231-236

[117] Schlick-Steiner BC, Steiner FM, Stauffer C, Buschinger A. Life history traits of a European Messor harvester ant. Insectes Sociaux. 2005;52:360-365. DOI: 10.1007/s00040-005-0819-8

[118] Meudec M. Cycle biologique de Tapinoma erraticum (Formicidae dolichoderinae). Annales de la Société Entomologique de France. 1973;9:381-389

[119] Mintzer A. Colony foundation and pleometrosis in Camponotus (Hymenoptera: Formicidae). Pan-Pacific Entomologist. 1979;55:81-89

[120] Brian M. The stable winter population structure in species of Myrmica. Journal of Animal Ecology. 1950;19:119-123. DOI: http://www.jstor.org/stable/1522

[121] Brian M. Ant culture for laboratory experiment. Entomologist's Monthly Magazine. 1951;87:134-136

[122] Brian M. Caste determination in a Myrmicine ant. Experientia. 1951;7:182-183. DOI: 10.1007/BF02148904

[123] Holmquist A. Notes on the life history and habits of the mound-building ant, Formica ulkei Emery. Ecology. 1928;9:70-87. DOI: 10.2307/1929544

[124] Holmquist A. Studies in arthropod hibernation. II. The hibernation of the ant, Formica ulkei Emery. Physiological Zoology. 1928;1:325-357. DOI: http://www.jstor.org/stable/ 30151051

[125] Scherba G. Reproduction, nest orientation and population structure of an aggregation of mound nests of Formica ulkei Emery ('Formicidae'). Insectes Sociaux. 1958;5:201-213. DOI: $10.1007 / \mathrm{BF} 02224070$

[126] MacKay E, MacKay W. Biology of the thatching ant Formica haemorrhoidalis Emery (Hymenoptera: Formicidae). Pan-Pacific Entomologist. 1984;60:79-87 
[127] Kondoh M. Bioeconomic studies on the colony of an ant species, Formica japonica Motschulsky, 1: Nest structure and seasonal change of the colony members. Japanese Journal of Ecology. 1968;18:124-133. DOI: 10.18960/seitai.18.3_124

[128] Imamura S. Observations on the hibernation of a polydomous ant, Formica (Formica) yessensis Forel. Journal of the Faculty of Science, Hokkaido University. Series VI, Zoology. 1974;19:438-444. DOI: http://hdl.handle.net/2115/27569

[129] Gösswald K, Bier K. Untersuchungen zur Kastendetermination in der Gattung Formica. 3. Die Kastendetermination von Formica rufa rufo-pratensis minor Gossw. Insectes Sociaux. 1954;1:229-246. DOI: 10.1007/BF02222948

[130] Gösswald K, Bier K. Untersuchungen zur Kastendetermination in der Gattung Formica. 4. Physiologische Weisellosigkeit als Voraussetzung der Aufzucht von Geschlechtstieren im polygynen Volk. Insectes Sociaux. 1954;1:305-318. DOI: 10.1007/BF02329615

[131] Otto D. Die Roten Waldameisen. Die Neue Brehm-Bücherei. Vol. 293, Wittenberg, Lutherstadt: A. Ziemsen Verlag; 1962. 151 p

[132] Schmidt G. Steuerung der Kastenbildung und Geschlechtsregulation im Waldameisenstaat. In: Schmidt GH, editor. Sozialpolymorphismus bei Insekten. Stuttgart: Wiss. Verlag; 1974. pp. 404-512

[133] Cagniant H. Cycle biologique de la fourmi Cataglyphis cursor Fonscolombe, Hymenopteres, Formicidae. Vie et milieu. Série C, Biologie terrestre. 1977;26:277-281

[134] Cagniant H. La parthénogenèse thélytoque et arrhénotoque chez la fourmi Cataglyphis cursor Fonsc. (Hym., Form.). Cycle biologique en élevage des colonies avec reine et des colonies sans reine. Insectes Sociaux. 1979;26:51-60. DOI: 10.1007/BF02283912

[135] Cagniant H. La parthénogenèse thélytoque et arrhénotoque des ouvrières de la fourmi Cataglyphis cursor Fonscolombe. Etude en élevage de la productivité de sociétés avec reine et de sociétés sans reine. Insectes Sociaux. 1980;27:157-174

[136] Dlusskiy G, Soyunov O, Zabelin S. Murav'i Turkmenistana [Ants of Turkmenistan]. Ashkhabad, Ylym. 1989. 273 pp. (in Russian)

[137] Marikovskiy P. Murav'i Pustyn' Semirech'ya [Ants of the Deserts of Semirechie]. AlmaAta: Nauka Kazakhskoy SSR; 1979. 263 pp. (in Russian)

[138] Kannowski P. Colony populations of two species of Dolichoderus (Hymenoptera: Formicidae). Annals of the Entomological Society of America. 1967;60:1246-1252. DOI: 10.1093/aesa/60.6.1246

[139] Torossian C. Recherches Sur la biologie et l'éthologie de Dolichoderus quadripunctatus (Hym. Form. Dolichoderidae). III. Étude expérimentale de l'action des principaux facteurs climatiques. Bulletin de la Société d' Histoire Naturelle de Toulouse. 1967;103:447-490 
[140] Torossian C. Recherches sur la biologie et l'éthologie de Dolichoderus quadripunctatus (L.) Hym. Formicoidea Dolichoderidae. I. Étude des populations dans leur milieu naturel. Insectes Sociaux. 1967;14:105-121. DOI: 10.1007/BF02223262

[141] Cole Jr A. A brief account of aestivation and overwintering of the occident ant, Pogonomyrmex occidentalis Cresson, in Idaho. Canadian Entomologist. 1934;66:193-198. DOI: $10.4039 /$ Ent66193-9

[142] Lavigne R. Bionomics and nest structure of Pogonomyrmex occidentalis (Hymenoptera: Formicidae). Annals of the Entomological Society of America. 1969;62:1166-1175. DOI: 10.1093/aesa/62.5.1166

[143] Hart L, Tschinkel W. A seasonal natural history of the ant, Odontomachus brunneus. Insectes Sociaux. 2012;59:45-54. DOI: 10.1007/s00040-011-0186-6

[144] Kipyatkov V, Lopatina E. Temperature and photoperiodic control of seasonal life cycles in ants (Hymenoptera, Formicidae). 1. Exogenous-heterodynamic species. Entomologicheskoe Obozrenie. 2003;82:801-819 (in Russian with English summary)

[145] Kipyatkov V. The role of endogenous rhythms in the regulation of annual cycles of development in ants (Hymenoptera, Formicidae). Entomologicheskoe Obozrenie. 1994;73:540-553 (in Russian with English summary, English translation in: Entomological Review. 1995;74:1-15)

[146] Lopatina E, Kipyatkov V. The influence of temperature on brood development in the incipient colonies of the ants Camponotus herculeanus (L.) and Camponotus xerxes Forel (Hymenoptera, Formicidae). In: Kipyatkov V, editor. Proceedings of the Colloquia on Social Insects. Vol. 2. Russian-speaking Section of the IUSSI, Socium: St. Petersburg; 1993. pp. 61-74

[147] Lopatina E, Kipyatkov V. The influence of daily thermoperiods on the duration of seasonal cycle of development in the ants Myrmica rubra L. and M. ruginodis Nyl. In: Kipyatkov V, editor. Proceedings of the Colloquia on Social Insects. Vol. 3-4. Russianspeaking Section of the IUSSI, Socium: St. Petersburg; 1997. pp. 207-216

[148] Lopatina E. Effect of daily thermoperiods on the duration of individual development in ants (Hymenoptera, Formicidae). Entomol. Obozr. 2003;82:537-547 (in Russian with English summary, English translation in: Entomological Review. 2004;83:1092-1101)

[149] Kipyatkov V, Lopatina E. Experimental study of seasonal cycle of rapid brood production in the ants Myrmica rubra L. and M. ruginodis Nyl. From two different latitudes. In: Kipyatkov V, editor. Proceedings of the Colloquia on Social Insects. Vol. 3-4. Russianspeaking Section of the IUSSI, Socium: St. Petersburg; 1997. pp. 195-206

[150] Kipyatkov V, Lopatina E. Seasonal cycle and winter diapause induction in ants of the genus Myrmica in the polar circle region. In: Kipyatkov V, editor. Proceedings of the Colloquia on Social Insects. Vol. 3-4. Russian-speaking Section of the IUSSI, Socium: St. Petersburg; 1997. pp. 277-286 
[151] Kipyatkov V, Shenderova S. Endogenous rhythms in reproductive activity of red wood ant queens (Formica rufa group). Zoologicheskii Zhurnal. 1990;69:40-52 (in Russian with English summary)

[152] BruniquelS. Observation Sur la biologie d' Aphaenogaster subterranean Latr. (Formicoidea, Myrmicidae). Etude experimentale du preferendum thermique. Bulletin de la Société d'histoire Naturelle de Toulouse. 1978;114:160-171

[153] Hölldobler B. Temperaturunabhängige rhythmische Erscheinungen bei Rossameisenkolonien (Camponotus ligniperda Latr. und Camponotus herculeanus L.) (Hym. Form.). Insectes Sociaux. 1961;8:13-22. DOI: 10.1007/BF02332768

[154] Soulié J. Action des facteurs du milieu sur le déclenchement et la rupture de l'état d'hibernation chez Crematogaster scutellaris Ol. (Hymenoptera: Formicoidea). Comptes Rendus des Seances de la Societe de Biologie. Paris. 1955;149:806-808

[155] Soulié J. Facteurs du milieu agissant sur l'activité des colonies de récolte chez la fourmi Cremastogaster scutellaris Ol (Hymenoptera, Formicoidea). Insectes Sociaux. 1955;2:173177. DOI: $10.1007 / \mathrm{BF} 02224102$

[156] Soulié J. Le déclenchement et la rupture de l'état d'hibernation chez Crematogaster scutellaris Ol. (Hymenoptera: Formicoidea). Insectes Sociaux. 1956;3:431-438. DOI: 10.1007/ BF02225763

[157] Soulié J. Quelques notes sur l'hibernation chez la fourmi Crematogaster scutellaris Ol. et chez une espèce voisine Crematogaster auberti Em. (Hymenoptera: Formicoidea). Insectes Sociaux. 1957;4:365-373. DOI: 10.1007/BF02224156

[158] Billen J. Stratification in the nest of the slave-making ant Formica sanguinea Latreille, 1798 (Hymenoptera, Formicidae). Annales de la Société royale zoologique de Belgique. 1984;114:215-225

[159] Dreyer W. The effect of hibernation and seasonal variation of temperature on the respiratory exchange of Formica ulkei Emery. Physiological Zoology. 1932;5:301-331. DOI: http://www.jstor.org/stable/30152792

[160] Brian M. Oviposition by workers of the ant Myrmica. Physiologia Comparata et Oecologia. 1953;3:25-36

[161] Brian M. Studies of caste differentiation in Myrmica rubra L. 5. Social conditions affecting early larval differentiation. Insectes Sociaux. 1962;9:296-310. DOI: 10.1007/BF02229629

[162] Brian M, Hibble J. Studies of caste differentiation in Myrmica rubra L. 7. Caste bias, queen age and influence. Insectes Sociaux. 1964;11:223-238. DOI: 10.1007/BF02222675

[163] Kipyatkov V.Studies of photoperiodic reaction in the ant Myrmica rubra L. (Hymenoptera, Formicidae). I. Main parameters of the reaction. Entomol. Obozr. 1974;53:535-545 (in Russian with English summary) 
[164] Kipyatkov V. Ecology of photoperiodism in the ant Myrmica rubra L. (Hymenoptera, Formicidae). 1. Seasonal changes in the photoperiodic reaction. Entomol. Obozr. 1979; 58:490-499 (in Russian with English summary, English translation in: Entomological Review. 1979;58:10-19)

[165] Kipyatkov V, Shenderova S. The effects of temperature and photoperiod on egg laying and productivity in red wood ant queens (Hymenoptera, Formicidae, Formica rufa group). Entomol. Obozr. 1991;70:36-46 (in Russian with English summary; English translation in: Entomological Review. 1991;70:13-24)

[166] Kipyatkov V. Studies of photoperiodic reaction in the ant Myrmica rubra. 4. Photoperiodic reactivation. Zoologicheskii Zhurnal. 1977;56:60-71 (in Russian with English summary)

[167] Hand L. The effect of photoperiod by the red ant, Myrmica rubra. Entomologia Experimentalis et Applicata. 1983;34:169-173. DOI: 10.1111/j.1570-7458.1983.tb03313.x

[168] Brian M. The importance of daylength and queens for larval care by young workers of the ant Myrmica rubra L. Physiological Entomology. 1986;11:239-249. DOI: 10.1111/ j.1365-3032.1986.tb00411.x

[169] Kipyatkov V, Lopatina E. Temperature and photoperiodic control of Diapause induction in the ant Lepisiota Semenovi (Hymenoptera, Formicidae) from Turkmenistan. Journal of Evolutionary Biochemistry and Physiology. 2009;45:238-245. DOI: 10.1134/ S0022093009020066

[170] Kipyatkov V, Lopatina E. Social regulation of larval diapause induction and termination by the worker ants of three species of the genus Myrmica Latreille (Hymenoptera, Formicidae). Entomol. Obozr. 1999;78:804-814 (in Russian with English summary; English translation in: Entomological Review. 2000;79:1138-1144)

[171] Kipyatkov V, Lopatina E. Vestigial photoperiodic response in subarctic Myrmica ants. Current Science. 2000;79:97-98

[172] Kipyatkov V. Studies of photoperiodic reaction in the ant Myrmica rubra L. (Hymenoptera, Formicidae). 5. Perception of photoperiodic information by an ant colony. Entomol. Obozr. 1976;55:777-789 (in Russian with English summary)

[173] Kipyatkov V. Myrmica prepares for winter. Science in the USSR. 1988;1:76-83

[174] Kipyatkov V, Lopatina E. Social regulation of larval development and diapause by the worker ants. In: Les Insectes Sociaux. In: 12th Congress of the International Union for the Study of Social Insects, Paris, Sorbonne, August 21-27, 1994. 1994. p. 317

[175] Tauber M, Tauber C, Masaki S. Seasonal Adaptations of Insects. New York, Oxford: Oxford University Press; 1986. XV+411 p

[176] Danks H. Insect Dormancy: An Ecological Perspective. Ottawa: Biological Survey of Canada (Terrestrial Arthropods); 1987. IX+439 p 
[177] Danks H. Key themes in the study of seasonal adaptations in insects II. Life-cycle patterns. Applied Entomology and Zoology. 2006;41:1-13. DOI: 10.1303/aez.2006.1

[178] Elmes G. The social biology of Myrmica ants. Actes des Colloques Insectes Sociaux. 1991;7:17-34

[179] Elmes G, Thomas J. Die Biologie und Ökologie der Ameisen Gattung Myrmica. In: Geiger W, editor. Tagfalter und ihre Lebensraume: Arten. Gefahrdung, Schutz, Basle: Schweizerischer Bund für Naturschutz; 1987. pp. 404-409 
